\title{
The Modern Italian Sculptor as International Entrepreneur: The Case of Medardo Rosso (1858-1928)
}

\author{
Sharon Hecker
}

\section{Performing the Sale of Modern Sculpture}

In 1899 the French poet Jehan Rictus recorded an encounter with Medardo Rosso, Italian sculptor and astute marketer, in his diary:

Medardo Rosso selling a reproduction to a bourgeois is [...] truly [...] comedic [...] He takes the unlucky guy, turns his nose to the wall enjoining him to stay in this penitent posture [...] Then he goes to a big Norman chest that conceals the work he wants to sell [...], opens a lid, plunges into the chest, brings out $[\ldots]$ a piece of $[. .$.$] plush cloth, [\ldots]$ drapes it on a wooden chest or a seat, $[\ldots]$ quickly runs to the window, plays with the curtains of the atelier for the illumination [...] And if the restless bourgeois risks glancing at these preparations, Rosso vehemently warns him not to move, reprimanding him 'Per Cristo, don't turn around!' Finally, after half an hour of beseechments [...], Rosso, having placed the wax [...] on the pedestal decorated by a plush cloth, declares: 'And now look!' The relieved bourgeois turns around $[\ldots]$ and $[. .$.$] declares - how superb it is$ and generally he buys. If he was not convinced he wouldn't dare confess this and would leave with the object anyway. ${ }^{1}$

1 The full quote is: 'Rosso vendant une reproduction à un bourgeois est étonnant à voir. C'est une vrai scène de comédie inoubliable. Il prend l'infortuné Michet, il le tourne le nez dans la muraille lui enjoignant de rester dans cette posture de pénitence jusqu'à ce qu'il lui dise de se retourner. Puis il va à un grand bahut normand qui recèle l'œuvre qu'il veut [lui] vendre. Il [en] ouvre un battant de porte, plonge dans le bahut, en retire un morceau de peluche vert ou noir selon, le dispose, le drape sur une caisse en bois, ou une selle, puis vite court à la fenêtre, fait jouer les rideaux de l'atelier pour l'éclairage, la lumière. Et si le bourgeois inquiet risque un œil vers ces préparatifs, Rosso véhémentement lui enjoint de ne pas bouger, ce en le tutoyant: "Per Cristo, né té [sic] retourné [sic] pas!." Enfin après une demi-heure d'adjurations et de recommandations, Rosso ayant situé la cire qu'il veut vendre sur le piédestal orné d'une peluche déclare: “Et mainténant [sic] régarde!." Le bourgeois se retourne soulagé et devant tant de précautions déclare-que c'est superbe et généralement achète.

(C) SHARON HECKER, 2019 | DOI:10.1163/9789004291997_010

This is an open access chapter distributed under the terms of the prevailing CC-BY-NC License at the time of publication. 
This account replicates well-known perceptions of the artist as an entrepreneurial vendor in the increasingly commercialised market for art that characterised the late nineteenth century. Like most artists of the modern era, Rosso had to make his living by selling his sculptures to a new class of bourgeois clients. He viewed himself as an exhibitor for a mass audience rather than for a specific patron, as well as a skilled entertainer and salesperson, feeling at once superior to, yet dependent on enticing often-unrefined buyers. Rosso's marketing approach was particularly flamboyant and creative. As a foreigner working in Paris, he had to work harder to develop creative sales tactics and make a niche for himself in the competitive art scene. Despite a new cosmopolitan attitude in Paris, foreigners like Rosso were still considered to be outsiders, revealing tensions between nationalism and internationalism. Even his close Parisian friend Rictus described Rosso as having all the double-dealing and astuteness of an Italian.' ${ }^{2}$

Rosso saw himself as an internationalist, a citizen of the world and a maker of art without borders. His intransigent cosmopolitan attitude both helped and hampered his success, for in this period sculptors were expected to be international minded but also to promote their national identity. Rosso never fully accepted categorisation by any nationality or integration within the nationally defined artistic movements that characterised this epoch. As an internationalist, he refused to take into account cultural differences, rendering problematic the necessary forms of interaction, exchange, compromise and diplomacy. Thus, although he could make contact with markets around Europe, he remained an outsider looking in.

Whether an artist was local or foreign, selling sculpture posed specific problems in the modern age. Despite the intensified internationalisation of the art markets, sculpture continued to be entrenched in national concerns, for monuments could not be internationalised: such large-scale works, which brought sculptors prestige and financial security, were costly to make, difficult to move, mostly site specific and firmly attached to national institutions. Thus, they were unmarketable as objects for a new class of mobile bourgeois buyers.

S'il était mal convaincu il n'oserait pas le confesser et s'en irait tout de même avec l'objet.' See: Bibliothèque Nationale, Département des Manuscrits, Paris, Papiers de Jehan Rictus, NaFr 16102, Journal 6, 12 May 1899, 41 R/V. Transcription by Alessandro De Stefani. The text was reproduced, with minor errors of transcription, in: Giovanni Lista, Medardo Rosso. Destin d'un Sculpteur (Paris: L'Échoppe, 1994), 152-3.

2 'Rosso [...] a toute la fourberie et l'astuce italienne.' Papiers de Jehan Rictus, NaFr16102, Journal 6, 12 May, 1899, 41R. Transcription by Alessandro De Stefani, published in Italian translation in: Giovanni Lista, Medardo Rosso. Scultura e fotografia (Milan: 5 Continents editions, 2003), 304. 
Advances in technology permitted the efficient manufacture of smaller serial reproductions, and this offered a promising new avenue for transnational circulation and profit. Casting and distribution remained nonetheless problematic: they were dependent upon a few powerful foundries that conformed to nationalistic agendas and forced sculptors to take a back seat to marketing. By the end of the century, serial sculpture's mass reproducibility and commercialisation also rendered its quality dubious and raised issues surrounding art's uniqueness, originality and authenticity. Rosso devised creative ways to bypass this problem by casting his own works serially and selling them as if they were original, unique sculptures.

In this essay I contend that Rosso is a rare example of an Italian sculptor who took advantage of the new international prospects for modern art that were developing in Paris and around Europe. ${ }^{3}$ I examine the evolution of Rosso's sales tactics from Milan to Paris to Europe at large within the context of markets for avant-garde sculpture, especially the possibilities and problems posed by the burgeoning serial sculpture industry. As a foreigner, Rosso was a displaced, nomadic and mobile subject and therefore was forced to rely on serial sculpture's new commercial possibilities. I maintain that he mobilised the sites of his sales. His career exemplifies the gradual shift from the sculptor's dependence on the public Salon for sales. He capitalised on his studio, independently organised shows and relied on commercial galleries to exhibit and market his works. Rosso took this new concept to an extreme: combining artisanal and modern, national and international approaches, he became a travelling salesman who attempted to no longer rely on location as a form of self-definition. Finally, via the publication of idiosyncratic photographs he made of his works, which he disseminated in newspapers, journals and exhibition catalogues around Europe, he reduced the need to present the object to a client in order to sell it. I hope this essay will contribute to a more nuanced understanding of the complex dynamics underlying the international marketing of avant-garde sculpture in the late nineteenth century.

\section{The Revolution of the Market for Modern Art in France}

France, and specifically Paris, played a decisive role in the transformation of the production, reception, and marketing of art during the second half of the nineteenth century. In their 1965 study Canvases and Careers: Institutional Change in the French Painting World, sociologist Harrison C. White and art

3 For a full account of Medardo Rosso's internationalism, see: Sharon Hecker, A Moment's Monument: Medardo Rosso and the International Origins of Modern Sculpture (Berkeley: University of California Press, 2017). 
historian Cynthia A. White argued that the demise of the Salon in the 1860 s forever altered the system by which art was distributed, opening the doors for smaller, more non-juried exhibitions in Paris and expanding the roles of critics and art dealers in the following decades. ${ }^{4}$ According to the Whites, government-controlled Salons with academic juries gradually ceased to be central to the building of French artistic reputations. New middle-class buyers-professional people, merchants and industrialists - rather than members of the upper classes, were now seeking smaller, less expensive paintings with modest themes, often appropriate to the decoration of the bourgeois home. An increasing number of private dealers emerged on the scene to serve these new clients.

The Whites' account of the Salon tradition giving way to new kinds of opportunities for French artists mediated by dealers was disputed in 2007 by economic historian David W. Galenson and art historian Robert Jensen. ${ }^{5}$ Galenson and Jensen demonstrated that the Salon's monopoly was not immediately replaced in the 186 os by a competitive market run by private dealers. Rather, the authors emphasised that the change in the market was first instituted by the smaller, artist-organised exhibitions, which offered new ways for artists, among them the impressionists, to develop their own markets. The authors opined that this shift to artist-driven organisations and sales of works also had an impact on the kind of art that was produced, since modern artists like the impressionists and neo-impressionists no longer had to rely on commissions from specific patrons and instead could paint whatever they chose and then look for an appropriate buyer. Galenson and Jensen concluded that painters gained greater artistic freedom as well as control over exhibitions and sales.

\section{The Case of Sculpture: The Enduring Role of the Salon}

Within these two accounts of the radical changes that took place in the French art market in the second half of the nineteenth century, sculpture is ignored. It is a commonplace that sculpture lagged behind avant-garde painting and generally remained more conservative than its sister art until the end of the century. This delay has been attributed to institutional controls: with rare exception, the most important sculptors of the time continued to establish their reputations by winning large public commissions, typically by producing monuments that reflected collective nationalistic and political concerns.

4 Harrison C. and Cynthia A. White, Canvases and Careers: Institutional Change in the French Painting World (New York: Wiley, 1965).

5 David W. Galenson and Robert Jensen, "Careers and Canvases: The Rise of the Market for Modern Art in Nineteenth-Century Paris," Van Gogh Studies (Current Issues in NineteenthCentury Art) 1 (2007): 137-66. 
Throughout the nineteenth century, even in the last decades under discussion here, official Salons still by and large created the reputations of French sculptors and allowed the successful ones to build a measure of financial security. ${ }^{6}$ This situation persisted even after the Salon had ceased to control the reputations of avant-garde painters. Given the high costs of production of large-scale sculptures, sculptors would first exhibit their best works as plaster models at the Salon or in academic exhibitions. If a model was selected, then the state (or, less frequently, members of the public by subscription, or wealthy private societies or patrons) paid for it to be converted into such expensive permanent materials as marble or bronze. Especially in France, the state supported the extensive costs of training sculptors and, as a return on its investment, would then acquire their large works destined for public official spaces. The state thus promoted favoured artists (this was true of preferred Salon painters as well), who were rewarded not only with state purchases but also medals, cash prizes, teaching positions, elections to national academies, exhibitions and the opportunity to sit on juries. Even the most progressive French sculptors of the time-notably Auguste Rodin, who is praised today for his autonomy — remained committed to institutional recognition in France during their lifetime. ${ }^{7}$

Although foreign sculptors such as Rosso could exhibit at the Salon, they could not hope to truly penetrate its insular system. They were thus obliged to find alternative ways to build a reputation and market. Monuments, in fact, remained the exclusive domain of French sculptors. Despite increasing openness to international ideas and foreign artists in Paris, it would have been inconceivable for a foreign sculptor to participate in a French national monument competition during this period, especially after France's defeat in the Franco-Prussian War of $1870-1 .^{8}$ State-commissioned monuments were intended to foster a sense of common national heritage and identity: war monuments celebrating French heroism, resistance, defence and revanche (revenge), as well as funerary monuments and tributes to French literary

6 For an overview, see: La sculpture française au XIX siècle (Paris: Réunion des musées nationaux, 1986).

7 A notable exception is Jean-Louis Barye, who built a career outside of the Salon.

8 On the tension between internationalism and nationalism in the arts in France after 1871, see: Rachel Esner, "Art Knows no Fatherland': Internationalism and the Reception of German Art in France in the Early Third Republic," in The Mechanics of Internationalism, eds. Martin H. Geyer and Johannes Paulmann (London: Oxford University Press, 2001), 357-74. 
genius or universal human values were all seen, with rare exception, as the proper preserve of French sculptors. ${ }^{9}$

By the time Rosso came to Paris in 1889, Rodin had engaged in repeated clashes with the establishment over his unconventional monument proposals. Rodin's presentation of innovative large-scale sculptures and his requests for official support for them put pressure on the Salon's power and conservativism, foreshadowing the breakdown between sculptors and the Salon's exclusive control over their careers, reputations and markets in the twentieth century. Eventually, this situation would further open the door to foreign sculptors in Paris, such as Constantin Brancusi and Alberto Giacometti, who gained fame and success without the need to build their reputations through official French channels such as the Salon.

\section{Serial Sculpture: A New Avenue for Commercialisation}

Even as French sculptors continued to depend on the Salon for certification of their reputations and acquisition of large-scale works, they also found profitable new options in the industry for mechanically reproduced serial sculptures, which had the potential to run the gamut from kitsch to avant-garde. In his seminal study of serial sculpture in nineteenth-century France, art historian Jacques de Caso notes that already from the 1840s, serial sculpture found an expanding place in society, which was characterised by a growing taste for fashionable, small-scale reproductions. ${ }^{10}$ While it was costly and labour-intensive to make large monuments, technical developments in French foundries made serial sculpture increasingly efficient to produce. The sand casting method, which required a significant division of highly specialised labour, dominated French foundry industries (in contrast to Italy, in which serial sculpture was made in a more artisanal fashion, primarily through the cire perdue or lostwax process). The expanding railroad system facilitated exportation of these smaller objects abroad. Thus, while the Salon continued to promote large-scale sculpture, smaller, serial sculpture gained a strong international presence by the 1870 .

9 June Hargrove, "Qui Vive? France: Sculpture of the Revanche," in Nationalism and French Visual Culture, 1870-1914, eds. June Hargrove and Neil McWilliam (New Haven - London: Yale University Press, 2005), 55-82. See also:June Hargrove, "Introduction," in Nationalism and French Visual Culture, 9-16.

10 Jacques de Caso, "Serial Sculpture in Nineteenth-Century France," in Metamorphoses in Nineteenth-Century Sculpture, ed. Jean Wasserman (Cambridge: Harvard University Press, 1979), 3 . 
Neither the model of the dealer-led system for painting hypothesised by the Whites nor the artist-led system theorised by Jensen and Galenson fits the case of the development of markets for modern sculpture. In the history of sculpture, a key role in marketing was played by foundries. Serial sculpture was an industry that involved many more components than painting. According to de Caso,

the profession of the sculptor [...] opened up to a much greater number of practitioners [...] The commercial exploitation of sculpture [...] became a large-scale enterprise. Public capital (i.e., the government) as well as private - that of the artists, the metallurgical industry, and retail dealers in this case - was invested in art both for profit and in order to further the development of industry.11

Important technical advances helped develop this market: Achille Collas's perfection of the pointing machine in 1836 made sculptural reductions simpler to produce. In partnership with French bronze founder Ferdinand Barbedienne, Colas soon created an empire for the production of serial sculpture, as did other French foundry businesses like Thiébaut, Christofle and Siot-Decauville. ${ }^{12}$ Art historian Neil McWilliam observes that serial sculpture during the subsequent decades became 'the most intensely capitalised area of French artistic production [...] [and the] demand for reproductive sculpture and decorative items had mushroomed, creating a highly competitive market controlled by a small number of specialist foundries. ${ }^{13}$

No other country could compete with France's command of the bronze casting industry, in particular the power of Barbedienne. As much a dealer as a founder, Barbedienne even directed major sculptors such as Jean-Baptiste Carpeaux on which subjects to make or sell. ${ }^{14}$ Until 1902 official limits on multiples were not recognised, nor were founders required to make contracts with sculptors that would restrict distribution. Only in the twentieth century, owing to legal interventions that have not yet been studied systematically, did

\footnotetext{
11 De Caso, "Serial Sculpture," 3.

12 Elisabeth Lebon, Dictionnaire des fondeurs de bronze d'art, France 1890-1950 (Paris: Marjon Éditions, 2003). On Barbedienne, see: Florence Rionnet, La maison Barbedienne: correspondances d'artistes (Paris: CTHS, 2008).

13 Neil McWilliam, "Craft, Commerce and the Contradictions of Anti-Capitalism: Reproducing the Applied Art of Jean Baffier," in Sculpture and its Reproductions, eds. Anthony Hughes and Erich Ranfft (London: Reaktion Books, 1997), 103.

14 Jacques de Caso, "Gustave Moreau, l'envers de la sculpture," in Gustave Moreau: l'homme aux figures de cire (Paris: Somogy, 2010), 10-1.
} 
industrially produced multiples become more restricted and subject to official control.

Unlike anything seen in the promotion and sales of painting, Barbedienne used aggressive and professional marketing techniques, such as the development of a network for exhibition and retailing that included printed catalogues and advertising. ${ }^{15}$ Barbedienne used his participation in industrial exhibitions and world fairs at home and abroad to advertise his goods, and his catalogues boasted medals and awards received throughout Europe, where he placed agents to promote his sales. Customers were encouraged to physically handle the objects on display, and this tactile aspect became part of these reproductions' commercial appeal. De Caso defines the situation as one of

supply and demand: [...] on the one hand, the conditions surrounding the creative processes which allow us to consider the works as already created in multiple, thanks to moulding operations; on the other hand, the deliberate multiplication of work for wide circulation in public and private whether for profit or not. ${ }^{16}$

It was Barbedienne whom Rosso approached upon his arrival in Paris in 1889, hoping to create a serial edition of one of his sculptures-but Barbedienne refused. Nonetheless, serial sculpture as a technique still became the best option for any sculptor to penetrate both the French and the international market.

There is as yet no systematic, comprehensive study of serial sculpture as a transnational market phenomenon. Such a study would include collecting patterns, buying preferences and tastes, and differences between domestic and international markets. This is necessarily related to ideas about the construction of value, and to the relationship of serial sculpture to growing international networks of exhibitions, dealers and agents that promoted these works. A thorough examination of the phenomenon should also include a study of the laws that governed the construction and transfer of these goods across borders. Finally, it should address the role of so-called "cultural mediators" (middlemen of various kinds, including art dealers, critics and literary figures, all of whom regularly travelled abroad or were otherwise familiar with cultural developments outside their home countries), as well as of private collectors, exhibition organisers and museum directors who began creating collections of national and foreign art.

\footnotetext{
15 McWilliam, "Craft, Commerce," 103.
}

16 De Caso, "Serial Sculpture," 2. 


\section{Sculpture as Unique versus Sculpture as Multiple}

Serial sculpture's popularity also posed problems. Its popularity created a tension between sculpture as high art and sculpture as multiple mass-produced objects. Barbedienne's name had become so powerful as a brand and status symbol that at times the name of the sculptor who modelled the work became obscured. This conflict led sculptors to seek new ways to benefit, yet also disengage, from the decorative/commercial aspect of their art. ${ }^{17}$ Some sculptors, such as James Pradier, made important statues for wealthy collectors and at the same time gave models to the industry to be reproduced as multiples. Others, like Jean-Louis Barye, were refused by the Salon and subsequently made only commercial works, which, in Barye's case, he personally cast in large series, thereby creating a reputation without the Salon's and a founder's approval. Other Salon artists gave models to the industry for reproduction but then regretted their decision: Auguste Clésinger attempted to escape the control of foundries, suing his founders to recover his work's artistic value. Still, major founders would continue to regularly prowl the Salons to find popularly and critically well-received large works in order to make small, saleable copies.

By 1870 the divisions became blurred between the unique high art object and the serial multiple, traditional and modern sculpture, "sculpture to see" and "sculpture to sell."18 The market abundance of industrial bronzes had significantly jeopardised the definition of sculpture as art, leading to questions of quality, authenticity and uniqueness that affected sculptors and the public alike. The generation of sculptors that came of age after 1870 was highly suspicious of industrial foundries and many began to publicly define their careers against them, although these younger sculptors still attempted to take advantage of the marketability of serial sculpture. Rodin, for example, closely supervised the quality of his casts and never ceded rights of reproduction to any founder. Rosso, whom Barbedienne likely rejected due to the sculptor's insistence on maintaining control, would begin casting his own works and making this fact publicly known in Paris after 1895 .

\footnotetext{
17 For studies of single French sculptors and their market strategies, see for example: Anne Middleton Wagner, Jean-Baptiste Carpeaux: Sculptor of the Second Empire (New Haven: Yale University Press, 1986), 175-207; Catherine Chevillot, ed., Emmanuel Frémiet: La main et le multiple (Dijon: Musée des Beaux-Arts, 1988); William Johnston and Simon Kelly, Untamed: The Art of Antoine-Louis Barye (Munich and New York: Prestel, 2006).

18 To rephrase Patricia Mainardi's definition of Salon painting. See: Patricia Mainardi, The End of the Salon: Art and the State in the Early Third Republic (Cambridge - New York: Cambridge University Press, 1993).
} 
The rising concern for quality can be seen in the growing demand by connoisseurs in France for casts made by the more artisanal cire perdue method during the last decade of the century (the technique had fallen into disuse in France earlier in the century), as described by art historian Elisabeth Lebon. ${ }^{19}$ Cire perdue implied a reduction of the number of practitioners involved. It also suggested that the sculptor could personally supervise the wax model before it was melted out of the mould to make the bronze. This led to a widespread belief that the resulting object, despite being a multiple, was more "authentic," "unique" and closer to the artist's hand. Since Rosso had experience with cire perdue from his early years in Italy, he would capitalise on his Italian roots to advertise this as a particularly valuable aspect of his works in Paris. As it turned out, familiarity with cire perdue became one way for sculptors outside the French establishment to penetrate the French market.

\section{Medardo Rosso's Early Marketing Strategies in Milan}

Rosso provides a rare example of a sculptor who made the transnational crossing by taking advantage of the popularity of serial sculpture while being careful not to cede to extreme commercialisation. His decision to move to Paris in 1889 made sense both from artistic and economic perspectives. The Italian market for modern sculpture in the 1880 s was much smaller and far more provincial than that of France. When Rosso began his career in Italy, the newly united country was caught up in a fragile moment of nation building. It was afflicted by political and economic crises. The unfulfilled promises of the Risorgimento had created an atmosphere of widespread pessimism. ${ }^{20}$ Poverty and illiteracy further obstructed Italy's already belated race to modernise, which inevitably had an impact on its avant-garde art scene. The effort to industrialise had resulted in fitful progress. The Italian government needed sculptors to fill the country's piazze with conservative equestrian monuments glorifying such heroes of Italian unification as Giuseppe Garibaldi, in order to reinforce a tenuous sense of national identity. ${ }^{21}$ Italian artists, especially sculptors, retreated

\footnotetext{
19 Elisabeth Lebon, Faire-Fonte au sable-Fonte à cire perdue (Paris: Ophrys Édition, 2012).

20 Gilles Pécout, Il lungo Risorgimento. La nascita dell'Italia contemporanea (1770-1922) (Milan: Bruno Mondadori, 200o).

21 Giovanna Massobrio, L'Italia per Garibaldi (Milan: SugarCo, 1982); Maurizio Corgnati, Gianlorenzo Mellini, and Francesco Poli, eds., Il lauro e il bronzo. La scultura celebrative in Italia. 1800-190o (Moncalieri: Ilte, 1990). For a more critical assessment, see: Lucy Riall, Garibaldi: Invention of a Hero (New Haven: Yale University Press, 2007); Lucy Riall, "Eroi maschili, virilità e forme della guerra," in Storia d'Italia. Annali 22. Il Risorgimento, eds.
} 
from the modern idioms, refusing or unable to integrate advances from abroad. Instead, many of them looked nostalgically to the country's illustrious past for inspiration - or sought to maintain the status quo. ${ }^{22}$

Most Italian critics and artists remained nostalgic for their country's glorious artistic past, which they believed could form the basis for a new art that might support a collective sense of national identity. In addition, suspicions about French cultural hegemony led many to reject the developments represented by French realism and impressionism throughout the 1880 s and $1890{ }^{23}$ Apart from a few enlightened private collectors, supported by a handful of art dealers and critics, there was no real market for avant-garde art in Italy.

Italian sculptors continued to meet the considerable commercial demand from abroad for highly crafted replicas of ancient and Renaissance sculptures. Unlike France, Italy's systems for producing and distributing serial sculpture remained locally based and provincial. It is no surprise that from 1890 until World War I, a wave of Italian founders immigrated to Paris in search of better jobs, bringing with them the specialised knowledge of bronze casting by the cire perdue method that eventually allowed them to dominate the burgeoning French foundry industry (this was also the case in London). ${ }^{24}$ Such transnational transfer of technical know-how suggests yet another way in which sculpture crossed national borders, although the phenomenon remains unstudied in France. Rosso too would capitalise on this Italian artisanal tradition, although he was careful not to become confused with a mere craftsman.

The unstable scenario in Italy left little scope for a rebellious avant-garde sculptor like Rosso, whose radical art served to emphasise rather than neutralise the national crisis. Indeed, no major monument by Rosso was ever erected

Alberto Mario Banti and Paul Ginsborg (Turin: Einaudi, 2007), 253-88; Ilaria Porciani, "Stato e nazione: l'immagine debole dell'Italia," in Fare gli italiani. Scuola e cultura nell'Italia contemporanea, eds. Simonetta Soldani and Gabriele Turi, vol. 1 (Bologna: Il Mulino, 1993), 385-428.

22 Sculptors such as Giuseppe Grandi experimented in their smaller works but not in their large-scale ones. See: Davide Martin Gariff, "Giuseppe Grandi (1843-1894) and the Milanese Scapigliatura” (PhD diss., University of Maryland, 1991).

23 On Francophobia in Italy, see: Federico Chabod, Storia della politica estera italiana dal 1870 al 1896 , vol. 1 (Bari: Laterza, 1951), 33-6.

24 There is no comprehensive account of Italian founders in Paris. On Italian founders in London, see: Duncan S. James, A Century of Statues: A History of the Morris Singer Foundry (Basingstoke: The Morris Singer Foundry, 1984); Susan Beattle, Alfred Stevens, 1817-75 (London: Victoria \& Albert Museum, 1975); Mapping the Practice and Profession of Sculpture in Britain and Ireland 1851-1951, University of Glasgow History of Art and HATII, online database 2011, http://sculpture.gla.ac.uk/view/person.php?id=ann_1356906205, accessed 5 October 2014; Steve Parlanti, The Parlantis: Art Bronze Founders of Fulham (London: Troubador Publishing, 2010). 
in Italy, although he entered several official competitions. His early, highly unconventional proposals for official monuments to Garibaldi (in 1882 and 1884), the first showing a seated, brooding Garibaldi rather than a resolute warrior on horseback or man of action and the second in which he abolished the figure of the hero from the monument altogether, were rejected. ${ }^{25}$ His idiosyncratic funerary monument in Milan for a distinguished public figure, Filippo Filippi (1889), the revered music critic of the Milanese daily newspaper $L a$ Perseveranza, was similarly attacked by critics as a sculpture 'pushed to disintegration [...] deplorable, without taste and without logic. ${ }^{26}$ Even enlightened Italian critics and collectors considered Rosso's roughly modelled heads and figurines depicting lower-class urban figures like La Portinaia (The Concierge, 1883-84) and the sleeping prostitute of Carne altrui (The Flesh of Others, 1883$84)$, innovative yet extreme. Most Italian academicians considered works like Rosso's, with their suggestion of social realism and rough, fragmented modelling style, to be outside the realm of such traditional desirable Italian qualities as il bello (beauty), for they believed that only beauty could 'elevate [the viewer] to the sublime. ${ }^{27}$

We have little documentation about Rosso's market in Italy, but evidence suggests that it could not have been substantial. No institutions record acquisitions of his works in the 1880s. Several of his early private sales in Milan allude to the artist's commercial naiveté or, perhaps, his sheer desperation: he sold a clay model of a work known as Bersagliere (ca. 1882), tinted in a bronze colour, to a collector named Gianatti, thereby opening the door to potential unauthorised copies. He also signed away his rights to a small figure group, Gli innamorati sotto il lampione (1883), to industrialist Pietro Curletti, allowing the owner to make as many copies as he wanted, (which the latter did), an agreement Rosso later regretted and tried to rescind without success in $1900 .{ }^{28}$

25 On Rosso's failed monument proposals, see: Sharon Hecker, "Il centro non può reggere: la monumentalità impossibile di Medardo Rosso," in Patrioti si diventa. Luoghi e linguaggi di pedagogia patriottica nell'Italia unita, eds. Arianna Arisi Rota and Matteo Morandi (Milan: Franco Angeli, 2009), 185-98.

26 'spinta fino alla scombiccheratura,' 'senza gusto e senza logica.' See: Federico Fontana, "I nuovi monumenti al Cimitero Monumentale di Milano," L'Italia, 2-3 November 1889.

27 'elevarci al sublime.' Avv. Giuseppe Bomben, "Esposizione delle opere di belle arti in Brera, VII," Il Secolo, 23 September 1869.

28 See letters from Medardo Rosso to Alberto Grubicy dated 11 August 1900, preserved in Archivio Medardo Rosso, Barzio. The relevant passage on Gianatti is published in: Paola Mola and Fabio Vittucci, Medardo Rosso. Catalogo ragionato della scultura (Milan: Skira, 2009), 226. The passage on Curletti is in Id., 235-6. 
The economic situation for all avant-garde artists in Italy during the $1880 \mathrm{os}$ was bleak. ${ }^{29}$ Even for traditional sculpture, there were few opportunities for exhibitions, like the Salons in Paris, which provided officially sanctioned showcases for marketing one's art. In Milan, where Rosso began his career, the annual Salone at the Accademia di Brera was the only available option aside from crowded national and regional exhibitions. No influential alternative venues emerged in Italy until the last decade of the century, and there was no official Italian exhibition for dissenters like the Salon des refusés held in Paris in 1863 .

\section{A Broadening Outlook: First Paris Exhibitions (1885-86)}

The dynamic nature of the Parisian art scene of the 1880 s, with its internationally renowned reputation for avant-garde art, the new exhibition and market opportunities provided for unofficial art, and, finally, a booming serial sculpture industry, explain its attraction for the young Rosso. Although Rosso was reticent about his early years in Italy, it is highly likely that his early knowledge of French artistic developments led him to believe he could infiltrate the French market. Rosso's network in Milan was comprised of sophisticated Francophile journalists, writers and literary critics who subscribed to French publications that included art reviews. A surviving album of Rosso's press clippings further attests to his attention to the goings on in French art in the 1880s. He therefore surely knew about French avant-garde art of the previous generation of realists being canonised in the French press. He could also not have been unaware of the fact that the first impressionist exhibition had occurred in 1874 and that impressionism was gaining international attention by the mid-1880s.

Rosso's decision to submit works to the French Salons of 1885 and 1886 was predictable, for Italian sculptors regularly sent sculptures to the Salons. ${ }^{30}$

29 Paola Martinelli and Alessandra Pino, "Il realismo sociale nelle mostre milanesi dal 1865 al 1915," in Arte e Socialità in Italia dal realismo al simbolismo 1865-1915 (Milan: Regione Lombardia. Assessorato agli enti locali e alla cultura, 1979), 227-47.

30 Matteo Gardonio, "Scultori italiani alle Esposizioni Universali di Parigi (1855-1889): aspettative, successi e delusioni" (PhD diss., Università degli Studi di Trieste, 2008), 98; Gianna Piantoni and Anne Pingeot, eds., Italie 1880-1910. Arte alla prova della modernità (Turin: Umberto Allemandi, 2000), 52; published also in French as Italies 1880-1910. L'art italien à l'épreuve de la modernité (Paris: Réunion des musées nationaux, 2001); Maria Beatrice Giorio, "Gli scultori italiani e la Francia. Influenze e modelli francesi nella prima metà del novecento" (PhD diss., Università degli Studi di Trieste, 2010-1). Pingeot's article and these dissertations demonstrate the significant presence of Italian artists at the Paris Salons and other exhibitions. This tradition must have influenced a young ambitious 
France played a key role in promoting the careers of foreign sculptors, who used Parisian Salon exhibitions as a launching pad both to achieve a stamp of approval for success back in their home countries as well as to establish international reputations. Rosso's unwillingness to show any of his newest works in the Salon suggests strategic caution. Taking advantage of his national origins, he submitted works on popular Italian themes, such as a bronze cast of the bust known in Italy as Bersagliere (ca. 1882) to the Salon of 1885 at the Palais des Champs-Élysées. ${ }^{31} \mathrm{He}$ now retitled it with a descriptive name that would be more appealing to foreigners: Bersagliere, tirailleur italien en vedette (Italian Marksman on a Scouting Mission). At the Salon of 1886, he showed bronze casts of his Mère et son enfant endormis (Mother and Her Sleeping Child, 1882) and his earlier Dopo una scappata, later known as Il Birichino but for this show retitled Gavroche (1882), thereby making an explicit reference to Victor Hugo's popular character from Les Misérables. ${ }^{32}$ Additionally, at some point in the 1880 s he prepared printed photographs of his sculptures with bilingual titles under them, likely intending them for circulation in France.

The French press took note of Rosso. In an 1886 review, for example, French critic and homme de lettres Edmond Thiaudière (himself a committed

sculptor like Rosso, although Gardonio does not examine Rosso's specific relationship to it or his different strategies with respect to his compatriots. Albert Boime believes that only Italian institutional limitations led Italian artists to exhibit in France. See: Albert Boime, The Art of the Macchia and the Risorgimento: Representing Culture and Nationalism in Nineteenth-Century Italy (Chicago: University of Chicago Press, 1993), 4. I believe that the reasons are more complex, especially in the case of Milan, a city that aspired to equal the French capital's cultural achievements.

31 François-Guillaume Dumas, ed., Catalogue illustré du Salon (Paris: Librairie d'art Ludovic Baschet, 1885), lxix, entry no. 4174. There were nearly 5,00o artworks exhibited in this show.

32 Rosso's name does not appear in the 1886 Salon catalogue, but his participation is confirmed in: Edmond Thiaudière, "Au Salon: La Sculpture—Les Bustes, II, Medardo Rosso," L'Opinion, 2 June 1886, as well as numerous other reviews. See: Langely, "La Sculpture Au Salon de 1886," Journal des artistes, 9 May 1886: 'un amusant Gavroche de M. Rosso,' (an amusing Gavroche by M. Rosso). Another article, listed by Rosso as "Langely" but undated and handwritten with the words 'Salon 86 ' reads: 'Sous l'escalier [...] une très originale esquisse de M. Rosso, une mère et son enfant endormis.' (under the staircase [...] a very original sketch by M. Rosso, a mother and her child asleep). See also: Louis-Pilate de Brinn'Gaubast, "L'Exposition des artistes indépendants," Le Décadent, 18 September 1886 (undated but written on top by Rosso 'samdi, 18 Sept.bre 86' [corrected from ' 87 ']): 'Mais toutes nos préferences sont pour les bustes en bronze de MM. Filleul et Rosso.' (But all our preferences go for the bronze busts by Mr. Filleul and Mr. Rosso.) See also: August Dalligny, "Le Salon de 1886," Journal des arts, 30 April 1886: 'des têtes de bronze bien accentuées par M. Rosso.' (well-accentuated heads in bronze by M. Rosso). See also: Anon., "L'Amore materno," L'Illustrazione italiana, 28 November 1886: 406 and 418. 
internationalist) singled Rosso out, stating in L'Opinion that the artist 'masterfully founds [...] impressionist sculpture. ${ }^{33}$ Thiaudière also commended Rosso for not ceding to Italian stereotypes: 'here is an Italian sculptor who happily avoids the usual Italianisms. He is not a lace needle-pointer in marble, making exquisite work, but a bit too affected and precious. ${ }^{34}$

Existing biographies register that Rosso exhibited at the small Salon du Groupe des Artistes Indépendants held in Paris in 1885 (a short-lived offshoot of the newly formed Société des Artistes Indépendants that had established an exhibition, free of juries, the previous year). He showed two of his earlier physiognomic bronze casts, a laughing old man originally titled Il Vecchio (The Old Man, 1883) and a laughing old woman originally titled Fine (End, 1883). However, Rosso strategically retitled the pair for the 1885 exhibition with the Ovidian names Philémon et Baucis (Philemon and Baucis). ${ }^{35}$ Although scholars have not noted possible reasons for this curious title change, it is tempting to imagine that he chose the names to recall the story of hospitality given by the old couple to strangers in a foreign land. French critics again singled these works out for their liveliness - to Rosso's great pleasure (although they were not his most radical or impressionistic works). It is worth noting that Rosso was the only Italian to exhibit in the show.

The opportunities these new independently run venues offered for foreign artists have not yet been studied systematically. Rosso's interest in engaging

'il fond magistralement la sculpture impressionniste.' Thiaudière, "Au Salon," 2.

'voici un sculpteur italien qui sort joliment des italienneries habituelles. Ce n'est pas un dentellier en marbre, faisant un travail exquis, mais un peu trop mièvre et précieux.' Thiaudière, "Au Salon," 2.

35 Robert Py, "Le Salon du Groupe des Artistes Indépendants," Revue moderne, 1 June 1885: 354: 'Bien nature aussi, les deux têtes en bronze de M. Medardo Rosso, qui se font pendant l'une à l'autre: Philémon et Baucis. Je place cependant Baucis au dessus de Philémon qui au point [de] vue de la couleur locale laisse bien un peu à désirer avec son petit bonnet de paysan Normand.' (Very natural are also the two bronze heads by Mr. Medardo Rosso, which are pendants: Philemon and Baucis. I place Baucus above Philemon who, from the viewpoint of local colour leaves something to be desired with her small Norman farmer's bonnet). This review is marked incorrectly in Rosso's scrapbook as being by Leon Riotor and the name of this author has been mistakenly repeated throughout the Rosso literature. See also: F. [sic] Hoffmann, "Le Salon des Indépendants," La Bataille, 4 June 1885: 2: 'Je donnerai une mention spéciale aux deux bustes en bronze de Philémon et Baucis, [part missing] fouillés, d'une touche grasse, signés Rosso, et au tableau de M. Lemanceau, le Moulin de la Galette, qui a de bien sérieuses qualitées.' (I would give special mention to the two bronze busts Philemon and Baucis [...] excavated, with a rough touch, signed Rosso, and the painting by M. Lemanceau, Moulin de la Galette, that have very serious qualities). Caramel misdates this review as 22 August 1886. Luciano Caramel, Mostra di Medardo Rosso (1858-1928) (Milan: Società per le belle arti ed esposizione permanente, 1979), 48. 
with the most avant-garde realms of French art indicates his attunement to new alternative options in Paris for foreigners. His growing desire to associate his art with that of the French avant-garde meant that he was also among only a handful of Italian artists to send work to the second Salon de la Société des Indépendants in Paris in 1886. Founded two years earlier by avant-garde painters such as Georges Seurat, Paul Signac and Odilon Redon, this Salon quickly became the main site for the promotion of post-impressionist painting. Again Rosso presented an older work, a bronze cast of La Ruffiana, but now under a far more neutral title-Portrait de vieille femme (Portrait of an Old Woman) along with his Bersagliere now described in the press generically as a 'buste d'un troupier' (bust of a trouper), ${ }^{36}$ both of which reflected the realist style of his earliest period rather than his more impressionistically sculptured works made around 1884. Rosso's caution paid off: through his participation in these exhibitions, he gained confidence and visibility. He also sold four of the works he exhibited in Paris in these years - the buyer listed as 'Pesce' in the margins of the original Hôtel Drouot auction catalogue, which has never been examined, was actually an Italian friend of Rosso's rather than a major international collector. ${ }^{37}$

36 This review is preserved in Rosso's scrapbook without the name of the journal signed "Un Passant," "Les On—dit," 22 August 1886, 2: 'A l'exposition d'à côté, groupe des artistes indépendants. M. Rosso expose deux bronzes vigoureux et bien vivants: une tête de vieille femme et le buste d'un troupier.' (At the exhibition next door, the group of independent artists. Mr. Rosso exhibits two vigorous and very lively bronzes: a head of an old woman and the bust of a trouper.) Rosso underlined the word 'vivants' in his scrapbook. The review was repeated in Le Reveil National on the same date. The information given in the chronology by Caramel for Rosso's exhibition of these works is incorrect. Caramel, Mostra di Medardo Rosso, 48. It is partially corrected by Giovanni Lista but without proper references for the changes. Giovanni Lista, Medardo Rosso: La Sculpture impressionniste (Paris: L'Échoppe, 1994), 13-4.

37 "Bronzes d'art et d'ameublement," Catalogue des Objets de curiosité, Hôtel Drouot, 17 February 1886, 11. 'No. 83-Bronze par M. Medardo Rosso: tête de bersagliere. (A figuré au Salon de 1885).' Price noted in margin: 52; 'no. 84-Têtes de vieillard et de vieille femme: Philémon et Baucis, bronzes par Medardo Rosso.' Price noted as 59; 'no. 85-Jeune femme et son enfant, bronze par Medardo Rosso.' Price noted as 39. The buyer's name in the margin, noted as 'Pesce,' was probably an acquaintance named Gaston (Gaetano) Pesce, who is described as 'addetto ingegnere all'Ambasciata d'Italia' (engineer of the Italian Embassy [in Paris]" in Gazzetta Ufficiale del Regno d'Italia, 7 September 1910: 4789. Lista believes that Rosso met Pesce during his military service in Pavia but produces no documentation to support this or his claim that Pesce also served in the same year. Lista, Medardo Rosso: Destin d'un sculpteur, 44. Lista finds a mention of Pesce in Gaetano Barbesi, L'indicatore della colonia italiana di Parigi (Paris: Tipografia del Risveglio italiano, 1905). Rosso had given Pesce's address in the Salon catalogue: 'chez M. Pesce, 23 rue Tronchet,' perhaps in order to be able to submit his works from a local address. No evidence suggests that Pesce 
Rosso's intuition of the value of expanding the international market for his work may have also encouraged him to sell casts to collectors in Vienna in the 1880 s by unknown means, although perhaps not the 'some sixty bronzes' exhorted in the Italian newspaper L'Illustrazione italiana. ${ }^{38}$ Seeking further international opportunities, he participated in the vast art show in the Italian Exhibition of 1888 in London organised by Milanese art dealer Alberto Grubicy (a rare forward-looking figure, who would later champion the divisionists). My consultation of original sales catalogues reveals that an important early international sale for Rosso was to British Army officer and politician Charles Balfour, who bought one of the four sculptures he showed in the London exhibition, although the price is not listed. ${ }^{39}$

\section{Rosso's Move to Paris (1889)}

Pursuing further international visibility, with the help of the Francophile Milanese journalist Felice Cameroni, Rosso moved to Paris. He first submitted five bronzes to another important Parisian venue-the 1889 exposition universelle. Since their inception in 1855 , the expositions universelles broadened the possible venues where foreigners could exhibit in Paris beyond the Salon. Unlike the Paris Salons, the expositions did not function according the old, state-sponsored paradigm since each pavilion had its own national jurisdiction. As a site for international exchange, the exposition universelle encouraged visitors from around the world to attend and numerous exhibitors spent significant time in Paris or decided to stay there. The show thus contributed to the growth of the Parisian international artistic community. It also provided a competitive venue for fame and markets as the Salon's power gradually waned.

submitted the works to the French Salons or sold them on Rosso's behalf without Rosso's knowledge, as is claimed by Alessandro Oldani, "Medardo Rosso, 1858-1928," in Medardo Rosso. La luce e la materia, ed. Paolo Zatti (Milan: 24 Ore Cultura, 2015), 115.

38 Anon., "L'Amore materno," L'Illustrazione italiana, 28 November 1886: 406 and 418.

39 Illustrated Catalogue of Alberto Grubicy's Picture Gallery in the Italian Exhibition in London, with a Preface and Biographical Notes by Vittore (Milan: Grubicy, 1888). Rosso's name is not mentioned in this catalogue. But see also: Report (translation) (London: Waterlow and Sons, 1889). Part Four-Regulations, Forms, Catalogue. Chapter III. Catalogue of the Fine Art Section. Class XV. SCULPTURE. Rosso's works are listed as number 1417 Golden Wedding, 1418 A Scamp [bronze], 1419 Oh that it were Whiskey, and 1422 A Street Boy. British Army Officer and politician Charles Balfour bought number 1418 A scamp. See: Antonella E.A. Bestaggini, "The Italian Exhibition of 1888 at Earl's Court" (MA Thesis, Courtauld Institute, 1990). Bestaggini does not mention Rosso's participation. 
Rosso remained in Paris after the show and was enthusiastically determined to access the market there. It might seem paradoxical given his desire to make avant-garde art that he immediately approached Barbedienne with photographs of his works and two bronzes, hoping the successful producer of serial sculptures would agree to create a marketable edition. He was clearly aware of Barbedienne's and serial sculpture's problematic reputation, for he optimistically wrote to his friend Cameroni in a letter from Paris: 'I will easily strike a deal [...] if Barbedienne intends to get out of his bronze candelabras this is the right time. ${ }^{40}$ However, as Rosso later told Cameroni, his efforts were not successful.

The market situation in Paris was shifting, but not fast enough for a foreign sculptor. Rosso was unsuccessful in his attempt to gain the support of new internationally minded dealers. A dealer's rejection was not uncommon for any artist without a reputation, since only a few of the known dealers in modern art in Paris were capable of establishing and promoting an artist's career in the 189os. Galenson and Jensen remark that 'dealers did not support young untried painters during the late nineteenth century: they rarely even showed their work. ${ }^{41}$ Rather, they continued to promote artists whose reputations had already been established.

One of the most noteworthy dealers approached by Rosso was Goupil \& Cie, which promoted artists seeking to expand their market. Goupil encouraged local and foreign artists who made huge history paintings to begin making small paintings from which they might produce printed reproductions and photographs. These were then distributed for consumption around the world. They also did the same with sculptures and even sold small sculptures, alongside paintings, in their gallery. ${ }^{42}$ Goupil's influence in the success of such expatriate

40 Comune di Milano, Biblioteca archeologica—Biblioteca d'arte-Centro di alti studi sulle arti visive—CAsva (Milano, MI), Lettere di Medardo Rosso a Felice Cameroni, http:// www.lombardiabeniculturali.it/archivi/complessi-archivistici/MIBAooCF9B/; Paola Rita Mola, "Medardo Rosso, due lettere a Felice Cameroni," E.S. 6 (1977): 121-6. Noted hereafter as "L:MR/FC." L:MR/FC 39. Mola also published L:MR/FC 8 here; L:MR/FC 1, 8, 18, 34, 39, 45 and 46 are in Paola Mola Kirchmayr, "Appendice," in Caramel, Mostra di Medardo Rosso, 98-9. Mentions of Barbedienne are found in: L:MR/FC 45, L:MR/FC 19, 31 January 189o, L:MR/FC 38, L:MR/FC 39, L:MR/FC 41 and L:MR/FC 50.

41 Jensen and Galenson, "Careers and Canvases," 160.

42 The Getty Research Institute's digitisation of the ledgers will reveal more about the worldwide scope of the Goupil enterprise not only in Paris but also throughout Europe. See: "Goupil \& Cie/Boussod, Valadon \& Cie Stock Books," The Getty Research Institute, http://www.getty.edu/research/tools/digital_collections/goupil_cie/. For an interesting first case study, see: Pamela Fletcher and Anne Helmreich, "Local/Global: Mapping Nineteenth-Century London's ArtMarket,"Nineteenth-CenturyArtWorldwide11,no.3(2012), 
Italian painters as Giuseppe de Nittis, for example, is well documented. But although Rosso would exhibit a few sculptures at the Boussod \& Valadon Gallery (formerly Goupil) in London in $1896,{ }^{43}$ Goupil evidently did not see a potential market for prints or for sales of his radical sculptures. Perhaps the gallery managers, like others Rosso had approached, sensed and disliked Rosso's desire for artistic autonomy.

Despite approaching dealers, Rosso's quest for artistic and commercial autonomy after his move to Paris distinguishes him from most of the other Italian sculptors there. In general, sculptors rarely enjoyed the same artistic acclaim or posthumous reputations as modern Italian painters like Giuseppe de Nittis, Giovanni Boldini or Federico Zandomeneghi, who adapted their work to impressionism and to the iconography of modern Paris. ${ }^{44}$ Some Italian émigré sculptors, like Emanuele Caroni, fully surrendered to the French market, promoting sales of their serially cast sculptures through prints made by Goupil. This led to excessive commercialisation. As art historian Matteo Gardonio laments, Caroni, like the other Italian artists who joined Goupil's stable, 'became swallowed up by economic dynamics, which led him to please the most frivolous and mundane middle class, setting aside any type of artistic desire. 45 Others, like Luca Madrassi, who had moved to Paris in 1869, ended up permanently stranded in the studios of famous French sculptors. Madrassi worked first for Pierre Jules Cavalier and then for Albert Carrier-Belleuse, in whose studio Rodin had got his start, sacrificing personal ambitions in order to survive. Madrassi represented the many talented Italian sculptors of the time who, as Gardonio notes, 'remained in the darkness of some French atelier' and whose

http://www.19thc-artworldwide.org/index.php/autumnı//fletcher-helmreich-mapping -the-london-art-market. Rosso mentions Goupil in L:MR/FC 5, 6 September 1889, L:MR/ FC 45, L:MR/FC 49. He speaks of a deal falling through in L:MR/FC 18. In L:MR/FC 17, 3 January 1890, he identifies the bronzes as Birichini. In L:MR/FC 21 he fears he lost the Goupil deal because he could not deliver bad casts.

43 A work described as 'small head of a boy' by Rosso is mentioned in a review in "Arts and Crafts," The Daily Chronicle, Monday, 3 August 1896, a clipping of which was found among Rosso's own press reviews. This and another Rosso wax may have been exhibited in the Boussod, Valadon \& Cie. gallery, but not in the Pre-raphaelite show listed by Mola and Vittucci, Medardo Rosso, 371. On Goupil's marketing of Italian painters, see: Marion Lagrange, Les Peintres italiens en quête d'identité. Paris 1855-1909 (Paris: INHA/CTs, 2009), 262-74. Also on Goupil and Italian artists, see: Maria Mimita Lamberti, "Il mercato della pittura italiana negli anni settanta," in Storia dell'arte italiana (Turin: Einaudi, 1982), 5-62. On Italian painters in Paris, see: Lagrange, Les Peintres italiens.

45 'venne inghiottito da dinamiche economiche, che lo portano ad accontentare la borghesia più salottiera, mettendo a parte ogni tipo di velleità artistiche.' See: Gardonio, "Scultori italiani alle Esposizioni Universali," 57. 
names are now forgotten. ${ }^{46}$ In hindsight, Rosso's strategy to maintain artistic autonomy served to enhance his reputation as an independent avant-garde artist.

Rosso did not have much success with other increasingly powerful Parisian art dealers such as Georges Petit (son of dealer Francis Petit). Dealers like Goupil, Petit, Paul Durand-Ruel and, later, Ambroise Vollard are now considered among the first entrepreneurs of the modern art world. Rosso must have known Petit's name from Milan and from Petit's exhibition in 1889 of Rodin's sculptures, along with paintings by Claude Monet, during the exposition universelle. In characteristically bold form, Rosso contacted Petit shortly after his arrival in Paris and announced to his friend Cameroni a future exhibition. But Petit does not appear to have shown Rosso's works in his lavish Parisian gallery at 8 rue de Sèze. This makes sense in the context of Jensen and Galenson's observation about the market in the nineteenth century that

never in the nineteenth century would dealers introduce and promote the reputation of an unknown artist [...] the absence of a steady demand by collectors for his work, and no dealer by himself could readily find the collectors who could create this demand. [...] Collectors' understanding of the principle that important art would be innovative was not yet sufficiently widespread to create large-scale demand for the work of young artists. $^{47}$

Only a few clients - among them opera singer Jean-Baptiste Faure-bought large numbers of impressionist paintings through dealers like Durand-Ruel, as Jensen and Galenson confirm. Yet collectors were not exclusively bound to dealers. I have found that Faure owned a small sculpture by Rosso, confirming that collectors like Faure also had direct contact with artists. ${ }^{48}$

As with all ambitious artists of his time, Rosso was keenly aware that international markets depended on the support of sophisticated cosmopolitan writers and critics, who now not only judged, but also publicised artworks,

46 Gardonio, "Scultori italiani alle Esposizioni Universali," 123. See also: Pingeot, "La scultura italiana vista da Parigi," in Italie 1880-1910, 52.

47 Jensen and Galenson, "Careers and Canvases," 157-8.

48 A wax cast of the Bambino ebreo (Jewish Boy) (c. 1892-94) whose provenance is attributed to Faure is currently in the collection of the Houston Museum of Fine Arts. On Faure and Durand-Ruel, see: Jensen and Galenson, "Careers and Canvases," 157. See also: Anthea Callen, "Faure and Manet," Gazette des beaux-arts (1974): 157-78. The work by Rosso in the Faure collection is mentioned in: Louis Piérard, Un sculpteur impressionniste: Medardo Rosso (Paris - Mons: Éditions de la Société nouvelle, 1909). 
connecting artists to dealers and patrons, and "explaining" or theorising about the latest artistic developments. Jensen and Galenson assert that, in this respect, the critics preceded the dealers, for in spite of their pioneering role in the distribution of modern art: 'dealers were [followers], not leaders in the development of modern art and its markets in the late nineteenth century. [They] played their role after talented painters had created the new art, and sophisticated critics had analysed it, and a body of collectors had come to buy it. ${ }^{39}$ I would like to suggest that it was not so much a matter of who preceded and who followed, but rather that this period was marked by the emergence of a web of relationships among artists, dealers, writers, critics, the audience and collectors, that together supported the international marketing of modern art.

It comes as no surprise that, like many aspiring artists of the time, Rosso made contact soon after his arrival in Paris with such famous literary figures as Émile Zola and Edmond de Goncourt, audaciously hoping that they would write about him. Both agreed to meet the young sculptor but neither ended up writing about him. Zola did allow Rosso to lend his name as the owner of Rosso's Il Birichino on exhibit at the exposition universelle of 1889, leading Italian newspapers of the time and many subsequent biographies of Rosso to claim that Zola actually bought the work. ${ }^{50}$ This was yet another strategy that Rosso employed to publicise his work and enhance his market interests.

Rosso would eventually find limited support from other writers. Secondgeneration symbolists like Charles Morice and Camille de Sainte-Croix, as well as Rosso's close friend, the poet Jehan Rictus, all later wrote lengthy articles about the artist, at times illustrated with Rosso's idiosyncratic photographs of his own works, in such Parisian literary journals as the Mercure de France and periodicals like Comøedia. ${ }^{51}$ Rosso's thirst to appear in these publications confirms his sense of Paris as an international tribunal of taste. Indeed, like most artists of his time, he understood that future foreign market success around Europe would depend on first establishing a reputation in Paris.

49 Jensen and Galenson, "Careers and Canvases," 160.

50 For a discussion of Rosso's meeting with Zola, see: Sharon Hecker, "Everywhere and Nowhere: Medardo Rosso and the Cultural Cosmopolitan in Fin-de-Siècle Paris," in Strangers in Paradise: Foreign Artists and Communities in Modern Paris, 1870-1914, eds. Susan Waller and Karen Carter (Aldershot: Ashgate, 2015), 143-54.

51 See, for example: Camille de Sainte-Croix, "Medardo Rosso," Mercure de France 17 (March 1896): 378-91; C. Morice, "Les Passants: Medardo Rosso," Le Soir, 25 September 1895, 2; Jehan Rictus, "Un Précurseur: Medardo Rosso," Comoedia, 3 January 1913, 1-2. See also: Yveling Rambaud, Silhouettes d'Artistes (Paris: Société Française d'Éditions d'Art, 1899), 229-32. 


\section{Developing New Strategies for Selling Sculpture in Paris (189os)}

During the 1890 os Rosso began to devise alternative strategies to market his sculptures in Paris. He trod a fine line between national and international approaches. While alluding to French impressionism in the subjects of his new works created in Paris and continuing to call his sculptures 'impressions,' he refused to fully commit to the movement's French overtones. He also capitalised on his Italian background to promote himself as a sculptor-craftsman who cast his own works in a foundry he set up in his studio. It is noteworthy that many of Rosso's creative survival strategies later became typical artistic features of modern art and involved new elements of performance.

One of these ways, perhaps in an effort to promote his reputation as an avant-garde sculptor, was for Rosso to refrain from further Salon exhibitions after 1895. In so doing, he placed himself outside the Salon, in line with avantgarde French artists who made highly experimental modern sculpture, such as Edgar Degas and Paul Gauguin. He showed his works only one time at a small but sophisticated exhibition in the foyer of a theatre called La Bodinière in late 1893-4. Exhibiting in this manner allowed him to be seen in a more intimate setting, to preserve control over his works and the way they were displayed in the show, while at the same time attracting the attention of the most avant-garde critics, collectors and artists of the time. It was at this show that Rosso met Rodin, which was publicised in Parisian papers. Following the show, newspapers also reported that Rosso and Rodin exchanged works as a sign of friendship.

Another strategy Rosso employed was to express big ideas in small-scale works. Since, as a foreigner, he was not eligible for official government commissions, he was forced to sustain himself in Paris almost entirely through small-scale sculptures intended for the middle-class market. Yet he also had to contend with the danger that their small size risked having his works too easily read as artistically insignificant commercial objects. It is this artistic reworking of the language of serial sculpture that has made Rosso one of the few sculptors of his time to have survived without a single large-scale sculpture to his name.

A third strategy involved relying on his technical training in Italy and his home country's reputation for craftsmanship, to create a mini foundry in his Paris studio and cast his own works. ${ }^{52}$ Rosso thus gained full control of his pro-

$5^{2}$ Rosso lived at various addresses during his Parisian years. Eugène Rouart, son of engineer and art collector Henri Rouart, recalled that in 1891, Rosso lived and cast his works in his father's factory on 137 boulevard Voltaire, directed by Henri's brother Alexis Eugène Rouart, “En souvenir de Medardo Rosso," L'Archer, nouvelle série 4 (1930): 281-5). However, 
duction process, fashioning for himself a unique status as a sculptor-founder while producing serial sculpture and benefitting from its popularity. At the same time he was uncomfortable with the impersonal quality of the multiple and was thus careful to make his works appear hand-modelled and hand-cast, so much so that for years scholars considered them to be unique objects. ${ }^{53}$

Whether as a survival strategy or for artistic reasons or both, in 1895 Rosso also began to exploit the new middle-class taste for cheaper sculptural materials and started to cast works in wax and plaster, selling them as finished pieces. He thereby successfully concealed the fact that he often could not afford bronze. By these actions he made a sharp departure from the French bronze foundry empire, pointing to the possibility of independence from its tyrannical power. Fortuitously, wax would eventually become the medium most associated with Rosso's name. His choice of wax and his rough surface modelling resonated with the French-identified word "impression," thereby allowing him to give a new sculptural twist to impressionist painting. Concomitantly, the fluid, dreamy quality of his waxes also aligned his sculptures with French symbolism.

Putting his modelling and casting skills to further use, Rosso began casting and selling copies of ancient and Renaissance sculptures, but signed with his own name. While making copies of antique works was not unique, and although a thriving international market for pastiches existed, copies of ancient art signed by modern artists seem unusual. In the 189os, he produced such objects as the gilded bronze head titled The Emperor Vitellius and the Head of an Ancient Roman Emperor in cement, both said to be copied from ancient busts, which he sold to the Victoria and Albert Museum on a visit to London in $1896 .{ }^{54}$ The process by which he made these copies is still not clear. It foreshadows the conceptual gestures of modern artists from Marcel Duchamp onwards, who

there was no metal foundry equipment in the boulevard Voltaire factory. In 1895 Rosso set up a foundry in his studio in Montmartre, at 50 rue Caulaincourt. He would also set up studio-foundries when he moved to 100 and then 98 Boulevard des Batignolles.

53 See: Sharon Hecker, "Reflections on Repetition in the Sculpture of Medardo Rosso," in Medardo Rosso: Second Impressions (New Haven - London: Yale University Press, 2003), 23-67; Sharon Hecker, "Fleeting Revelations: The Demise of Duration in Medardo Rosso's Wax Sculpture," in Ephemeral Bodies: Wax Sculpture and the Human Figure, ed. Roberta Panzanelli (Los Angeles: J.P. Getty Trust, 2008), 131-53.

54 See letter to Rosso from South Kensington Museum dated 26 September 1896 (Archivio Museo Rosso, Barzio). Volker Krahn hypothesises that early in his career, Rosso sold copies of Renaissance sculptures as originals, and that Wilhelm von Bode purchased one unknowingly in London in 1894. See: Volker Krahn, "Pastiche or Fake? A 'Donatello' by Medardo Rosso," Apollo (June 2009): 40-7. Mola and Vittucci refute this. See: Mola and Vittucci, Medardo Rosso, 340. 
claimed their authorship of historical artworks, which they reproduced and reworked as a form of critical contemporary reference.

Rosso also generated special excitement around his sculptures by opening his casting processes to the public. He again used his experience in Italian foundries, where the cire perdue method was regularly employed for casting bronzes, to play up his knowledge of a method that was particularly rare in order to appeal to refined collectors in Paris. He began publicising this talent on his business cards, in interviews given to journalists and in his letters to collectors. He further deployed publicity strategies through carefully choreographed studio photographs and personal letters to clients in which he appeared to divulge his special secret recipes for casting and patinating bronzes. ${ }^{55}$

After 1900 Rosso began holding casting parties in his studio in which he would dramatically cast bronzes in front of his guests' eyes using the cire perdue method-and then serve champagne to everyone. This generated an atmosphere of excitement for viewers at having witnessed a moment of creation and re-established the power of the artist, which had been taken away by the foundry industry. What had become part of the industrial process was thus restored to the hand of the sculptor. These events were recorded in the diaries of Rictus and in newspaper reviews by Parisian critics such as Louis Vauxcelles. The audience found them so exciting that one such incident of Rosso in the act of creation was recaptured in a novel by journalist André Ibels and novelist Georges de Lys: Rosso inspired their fictional character, 'Medardo Rosso,' a flamboyant Italian sculptor, in their 1908 French roman d'art titled L'Arantelle (The Spider Web). One finds descriptions in the press of Rosso as a modernday Benvenuto Cellini, and his performances of the act of making prefigured the action paintings of Jackson Pollock captured on film by photographer Hans Namuth. All these approaches contributed to the development of Rosso's new "sculptor-founder" persona.

Yet while Rosso promoted his sculptures as unique and original and emphasised his personal role in making them, I believe that his approach allowed him to take advantage of international art markets for multiples. Indeed, the serial production of his sculptures would play a key role in increasing Rosso's visibility around Europe after 1900, by which time he had practically ceased making any new subjects but for one final work (Ecce puer, 1906).

55 See, for example, the letter from Medardo Rosso to collector Gottfried Eissler dated September 1903 in: Archivio Storico di Arte Contemporanea (ASAC), Venice, Lettere di Medardo Rosso a Gottfried e Hermann Eissler, CA 14, file "Medardo Rosso," unpublished except for three letters, two of which are dated September 1903 and a third undated, which have been published with errors of transcription by Lista, Medardo Rosso, 99-107. 
Rosso's multiple new marketing tactics and publicity acts notwithstanding, his economic status as a foreign sculptor in Paris remained difficult throughout the $1890 \mathrm{os}$. He found only sporadic support from a sophisticated but limited avant-garde clientele, such as the engineer and art collector Henri Rouart, the French collectors Paul-Arthur Chéramy and Isidore Montaignac, and a meningitis expert named Dr. Sylvain Noblet, as well as an equally restricted circle of enlightened critics who hailed his art as revolutionary. He did garner press notices during the Balzac affair of 1898 , when Rodin was accused by several critics of having appropriated Rosso's ideas for his monument to the French literary giant. Part of Rosso's difficulties stemmed from his notorious carelessness with money-he seems to have frequently borrowed significant sums (his letters to collectors are replete with requests for money and he relied heavily on support from patrons), was overly generous with friends and spent everything he earned. His refusal to adapt and compromise, which led to financial difficulties, at the same time allowed him to escape criticism at home about excessive artistic and commercial accommodation or selling out to France. This contrasted with the treatment of Italian expatriate painters such as De Nittis, winner of the 1878 Légion d'honneur, who had been derided by Italian critics for 'making himself Parisian' and 'abandon[ing] himself to the genre sought by the public. ${ }^{56}$

\section{Expanding Pan-European Markets for Modern Sculpture (1900-10)}

By 1900 it became clear to Rosso that being in Paris would not suffice to create a truly international reputation, disseminate his revolutionary ideas and leave a lasting material legacy. He began to travel around Europe to promote and sell his art, relying on international networks and new market opportunities that characterised the period. Continuing to make reproductions of his serially produced subjects from Paris, he participated in several European shows and sold works around Europe between 1900 and 1910: Amsterdam, Utrecht, The Hague, Rotterdam, Dresden, Berlin, Leipzig, Vienna, Paris, London, Brussels and Florence.

The historical turning point was the exposition universelle in Paris of 1900, which functioned as a site for spontaneous international exchanges. Scholars point to three events held in conjunction with this exposition that shaped a foreign market for French impressionism. Yet there is no detailed description

56 Diego Martelli, "Exposition des Beaux Arts à Paris 1870," La Rivista Europea, 1 June and 1 August 1870, quoted in Lagrange, Les Peintres italiens, 90. 
of the process by which impressionist painting's success paved the way to the economic success of modern sculpture. The Centenale exhibition of French painting from 1878 to 1889 established impressionism as central to the French tradition in a final divorce from Salon art and made this faction known to the international visitors of the exposition universelle. ${ }^{57}$ Through this show, most Europeans gained awareness of impressionism and its modernity. ${ }^{58}$ Additionally, the display of Gustave Caillebotte's impressionist collection at the Musée du Luxembourg reinforced impressionism's supremacy and importance. Third, and specifically related to modern sculpture, Rodin was crowned as France's greatest living sculptor through the largest retrospective of his works mounted in Rodin's personal Alma Pavilion. ${ }^{59}$ The combination of these events paved the way for modern sculpture's entrance into European markets.

Rosso had apparently hoped to promote his work to the world alongside French avant-garde art by exhibiting in the French Pavilion of the exposition universelle. Despite the fact that he had lived in Paris for over a decade, he was still an Italian citizen and was forced to exhibit in the Italian Pavilion. There European cultural operators could first see and assess the marketability of his art. ${ }^{60}$ One was the wealthy Dutch writer, artist and art critic Etha Fles. Captivated by Rosso's art, she became his lover, patroness and supporter. Fles had come to Paris to help the Dutch commissioners select paintings at the exposition for an impressionist show in Holland.61 The ensuing Dutch exhibition reframed Rosso for international audiences within French impressionist art. It included paintings by Georges d'Espagnat, Gustave Loiseau, Camille Pissarro, Maxime Maufra, Claude Monet, Henry Moret, Pierre-Auguste Renoir and Alfred Sisley, and five sculptures by Rosso, and travelled to Amsterdam, Rotterdam, Utrecht and The Hague (Fig. 8.1). ${ }^{62}$

57 Robert Jensen, Marketing Modernism in Fin-de-Siècle Europe (Princeton: Princeton University Press, 1994), 164.

58 Jensen, Marketing Modernism, 67.

59 Rodin en 19oo. L'exposition de l'Alma (Paris: Réunion des musées nationaux, 2001).

6o Rosso refused to exhibit the works that were authorised (see unpublished letter to Rosso from Camera di Commercio Italiana in Parigi dated ${ }_{15}$ April 1900 with his annotations, preserved in Archivio Medardo Rosso, Barzio). His name does not appear in the catalogue. For works exhibited, see: Anon., "A L'Exposition," L'éclair, 22 May 19oo: 2.

61 She had come under the auspices of the Amsterdam society Arti et Amicitiae, of which she was a charter member. See: Margaret Scolari Barr, "Medardo Rosso and his Dutch Patroness," Nederlands Kunsthistorisch Jaarboek 13 (1962): 223.

62 Caramel gives the dates as January to April in Caramel, Mostra di Medardo Rosso, 51. Mola and Vittucci claim that the show travelled until May in Mola and Vitucci, Medardo Rosso, 372. The exhibition catalogue cover notes the dates as January-February, see: Tentoonstelling van schilderijen uit de moderne Fransche school en beeldhouwwerken van 


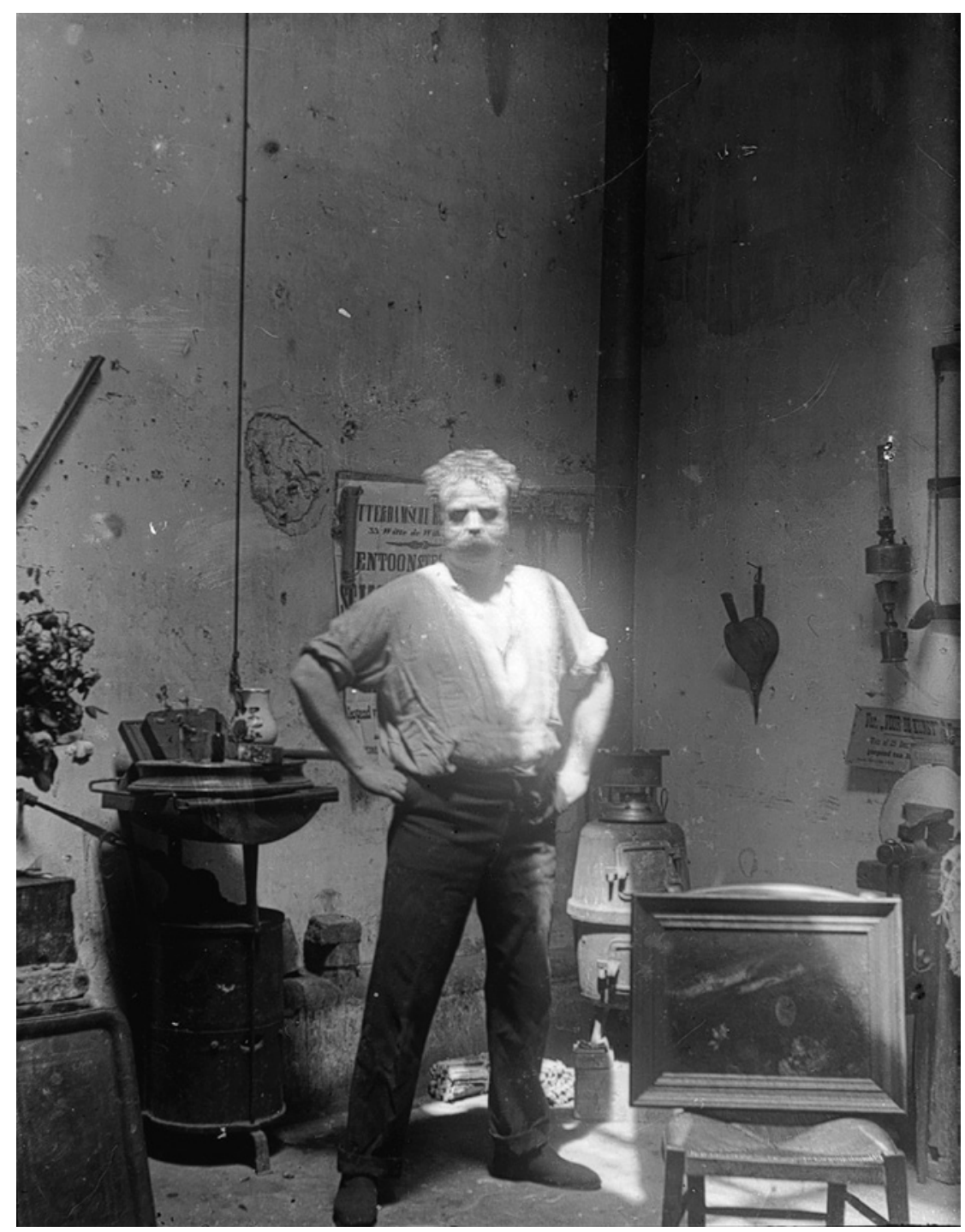

FIGURE 8.1 Medardo Rosso, Self-Portrait in Studio with Exhibition Poster "Tentoonstelling van schilderijen uit de moderne Fransche school en beeldhouwwerken van M. Rosso" in background, post-1901 
Rosso believed he would be welcomed in Holland, optimistically stating that, 'in the country of Hals and Rembrandt where people hate the academic, I shall be understood. ${ }^{63}$ He hardly garnered any press, however. Art historian Margaret Scolari Barr hypothesises that this was because only one of his bronzes arrived in Amsterdam in time for the opening. Although his Dutch supporter, Fles, wrote glowingly in a review that in Paris and Vienna the casts of Rosso's work command prices that surpass our imagination, therefore he is not interested in selling here, ${ }^{\prime 64}$ the exhibition was also clearly intended as a commercial enterprise. Fles's personal copy of the catalogue includes handwritten prices for Rosso's works, but no records or objects have emerged to assess whether any were sold (although Fles had amassed a significant collection). ${ }^{65}$ Given that this would be Rosso's only exhibition in Holland, one might surmise that the sales strategies did not generate a hoped-for international market.

\section{Markets for Modern Art in Central Europe (1901-2)}

Existing biographies recount Rosso's subsequent exhibitions and sales in Berlin, Dresden and Leipzig between 1901 and 1902 as a resounding success. I am convinced, however, that German attention to Rosso was contextually determined and the market for his art ambivalent. Although Fles may have been involved, the German interest belongs to what Jensen has described as Central Europe's investment in transforming French impressionism into a panEuropean modern phenomenon. Rosso's search for new markets there confirms that the greatest buyers of impressionism were outside of France. ${ }^{66}$ In my opinion these German exhibitions led to Rosso's inclusion in the landmark Vienna Secession of 1903, the show that definitively reshaped French impressionism into a transnational "origin" of modern art. This construction was codified the following year by one of the Secession's masterminds, German art historian and critic Julius Meier-Graefe, whose first edition of the seminal

M. Rosso. Januari-Februari 1901 (s.l.: Arti et Amicitiae, 1901). Barr also cites from the catalogue the works exhibited. Mola and Vittucci make several amendments to this list without citing an alternative source.

63 This article by Etha Fles in the Nieuwe Groningsche Courant dated 1 March 1901 is cited in translation but without its title in: Barr, "Medardo Rosso," 224.

$64 \quad$ Ibid.

65 Barr, "Medardo Rosso," 223.

66 Jensen, Marketing Modernism, 50. 
Entwicklungsgeschichte der Modernen Kunst (Origins of Modern Art, 1904), included a nine-page chapter entitled 'Medardo Rosso.' ${ }^{67}$

An example of Rosso's new sales tactics in Central Europe emerges through an examination of his exhibition of eight sculptures at the Albertinum in Dresden, probably in June 1901, thanks to Georg Treu, the museum's internationally minded director and curator of its Sculpture Department. ${ }^{68}$ Dresden's institutional interest in Rosso is not surprising: it had been the first German city to witness exhibitions and sales of modern French art since the $1890 \mathrm{os}$. Treu only bought one small work from Rosso: a wax version of Enfant malade (Sick Child, 1893-95), for 1,60o marks in July $1901{ }^{69}$

Undaunted, and intuiting Treu's background as an archaeologist and his interest in ancient art, Rosso subsequently sold Treu one of his "copies" of an ancient work, Head of Vitellius, for the far lower sum of 400 marks in March or April 1902, to be placed in the section of the museum that housed copies from the antique. ${ }^{70}$ Rosso insisted that his name appear on a label beside the work. ${ }^{71}$ Rosso did not succeed in his attempts to sell Treu another copy, Roman Senator, in 1903, despite allusion to financial difficulty and an offer to lower the price. ${ }^{72}$ Rosso donated a plaster version of his radical figure group, Une Conversation (A Conversation, ca. 1892-99) in the same month as he sold the Head of Vitellius. But this sculpture can no longer be found in the museum's collection. ${ }^{73}$

67 Julius Meier-Graefe, Entwicklungsgeschichte der modernen Kunst (Stuttgart: Julius Hoffmann, 1904). Republished in English as Modern Art: Being a Contribution to a New System of Aesthetics (London: W. Heinemann, 1908). The chapter was removed from subsequent editions.

68 See letter from Medardo Rosso to Georg Treu (hereafter L:MR/GT), s.d. from Paris: 'C'est [something erased] celle ci 8 œuvres que j'expose.' All letters to Treu are preserved in the Archive Staatliche Kunstsammlungen, Dresden, Skulpturensammlung, and are unpublished. This letter contradicts Mola and Vittucci, who claim that Rosso repeated the Dutch tour of five works in Mola and Vittucci, Medardo Rosso, 372. In L:MR/GT (but addressed to Treu's secretary), s.d., Rosso asks Treu to let Fles add a wax from her collection.

69 L:MR/GT 9 July 1901.

70 The transaction is recorded in four letters. See L:MR/GT.

71 The receipt reads 'riproduzione da mia mano,' replaced by 'riproduzione fatta di mia mano.' L:MR/GT, s.d. He repeates this as: 'Riprodotto e fuso da Medardo Rosso dall'originale del Vaticano a Roma,' L:MR/GT s.d.

72 L:MR/GT 18 June 1903 and 10 July 1903.

73 Mola and Vittucci give conflicting accounts: that it was sold, and that it was a gift, in Mola and Vittucci, Medardo Rosso, 200 and 372 respectively. The Dresden museum Inventory Register notes its entry on 22 March 1902 as 'geschenk' (gift) (Archives Staatliche Kunstsammlungen, Dresden). 
Rosso also exhibited in a commercial art gallery in Berlin in January 1902. ${ }^{74}$ Berlin, the economic and political capital, superseded all regional art capitals and had the greatest growth of art galleries, which dominated contemporary art in the late 1890 s and 190os. Rosso's show was held in Keller und Reiner, one of the leading prestigious galleries. I believe that Keller und Reiner chose to exhibit Rosso's works as part of its internationalist marketing strategy. By 1900 ambitious German dealers became convinced that modernist art sold well and was a good long-term investment. ${ }^{75}$ Fierce competition among galleries led to the importation of foreign art and a lucrative expansion of the contemporary art market in Berlin. More than the French, therefore, German gallerists courted international artists. In the spring of 1900 alone, Keller und Reiner held exhibitions of the Berlin artists Ludwig von Hofmann and Walter Leistikow, the Parisian Étienne Moreau-Nélaton and the Belgian Fernand Khnopff. Reviews confirm that German critics and dealers were framing Rosso through the lens of French "impressionist sculpture," which was reinforced by the publication of political journalist Edmond Claris's enquête, De L'Impressionnisme en sculpture (1902). In this piece of pro-Rosso propaganda, Claris interviewed major artists, critics and dealers about impressionism's relationship to sculpture. The book, for which Rosso had provided as illustrations his idiosyncratic photographs of his sculptures, first appeared in French, but was translated into German and republished by Fles in Utrecht, proving that Dutch, German and French markets were now becoming interconnected and open to the marketing of modern sculpture. ${ }^{76}$

Despite the non-commercial veneer of Keller und Reiner, this was clearly an economic venture intended to entice private collectors and appeal to museum directors. The show likely convinced Treu to buy Rosso's Vitellius copy in March or April 1902, and industrialist Walther Rathenau to buy a Tête de jeune fille (Head of a Young Girl; medium unspecified) for 1,500 marks in

74 Caramel, and Mola and Vittucci date the opening to February in Caramel, Mostra di Medardo Rosso, 35; Mola and Vittucci Medardo Rosso, 372. However, a letter from Keller und Reiner to Rosso dated 24 January 1902 suggests that the show opened in January (Archivio Medardo Rosso, Barzio), a fact that is confirmed in R.D., "Aus dem Berliner Kunstleben," National Zeitung, 24 January 1902. Mola and Vittucci hypothesise that he exhibited thirteen sculptures and seven photographs, and that these same works went to Leipzig a few months later, but cite no evidence for this. See: Mola and Vittucci, Medardo Rosso, 372 .

75 Jensen, Marketing Modernism, 74.

76 Edmond Claris, De l'Impressionnisme en sculpture: lettres et opinions de Rodin [et al.] (Paris: Éditions de La Nouvelle Revue, 1902). On Claris and the book's genesis, see: Edmond Claris, Souvenirs de soixante ans de journalisme 1895-1955 (Paris: José Millas-Martin, 1958), $30-2$ and $137-9$. 
September $1903 \cdot{ }^{77}$ Harald Gutherz, a German scholar, bought a bronze Il Birichino (1882), and Karl Ernst Osthaus, who was amassing a collection of French impressionist art in Hagen, bought a bronze Bambino ebreo (Jewish Boy, $1892-94) .78$

Subsequently, no city museum purchased Rosso's works and he never exhibited again in Berlin. Hugo von Tschudi, the director of the National Gallery, who had brought modern art to Berlin and was introduced by Treu to Rosso, seemed uninterested in an acquisition. ${ }^{79}$ Rosso's contact with Wilhelm von Bode, at the time curator of the Kaiser Friedrich Skulpturensammlung and a member of Berlin's cultural establishment, did not lead to sales, either. Bode was responsible for the museum's collection of plaster casts and an expert in Renaissance bronzes. Letters from Rosso to Bode disclose that Rosso promoted himself to Bode as an expert founder by claiming to divulge "secret" patination recipes. Rosso also repeatedly asked Bode for introductions to collectors.

Rosso's attempts at contacting possible venues in Germany were more successful in the case of Richard Graul, the director of the Museum der bildenden Künste in Leipzig, introduced to him by Treu. Graul held a one-man show of Rosso's works, whose title can now be confirmed as Kleinplastik in Bronze, Wachs und Papiermasse des Impressionisten Medardo Rosso, Paris, in June $1902 .{ }^{80}$ As with Keller und Reiner, the internationally minded Graul

77 Letter from Medardo Rosso to Walter Rathenau dated 25 September 1903 (Archivio Medardo Rosso, Barzio). Caramel mistakes this for a sale to the Berlin Museum in Caramel, Mostra di Medardo Rosso, 52 . Mola believes that the work, now lost, was a copy from the antique in Mola and Vittucci, Medardo Rosso, 338. However, I believe it could also have been a bronze version of Rosso's Bambina che ride.

78 Mola and Vittucci give the sale date as 'end of July-early September' but cite no source in Mola and Vittucci, Medardo Rosso, 292.

79 L: MR:GT, s.d.

8o Jahresberichte/Verein Kunstgewerbemuseum Leipzig, and Städtisches Kunstgewerbemuseum Leipzig, 125; Jahre Museum für Kunsthandwerk Leipzig Grassimuseum, v. 2/1, both unpublished; Olaf Thormann, Die Museumschronik von den Anfängen bis zum Jahr 1929 (Leipzig: Passage-Verlag, 2003), 67. The opening date is uncertain, but the museum's shows normally lasted for a month. Caramel (Mostra di Medardo Rosso, 53), believes it was in autumn, but Mola and Vittucci claim it was June, citing no source (Medardo Rosso, 372 ). See note 80 below for a review of 25 September 1902, suggesting it opened in that month. For Rosso's description to Treu of his first meeting with Graul, see L:MR/GT, s.d. but from Leipzig. Graul returned the works on exhibition to Rosso with a packing list, itemising thirteen bronzes (see letter from Richard Graul to Medardo Rosso, hereafter L: RG/MR, 29 November 1902, Archivio Medardo Rosso, Barzio). Mola and Vittucci claim that these were actually six bronzes and seven waxes, as well as seven photographs, but do not cite a source for the discrepancies with respect to Graul's list. In 1908, the museum library registered a gift from Rosso of Claris's publication in German (see note 75 above). 
linked Rosso with "impressionist sculpture." ${ }^{81}$ Graul had been the Zeitschrift für bildende Kunst's Paris correspondent and was on the editorial board of Pan, the German arts and literary magazine published from 1895 to 1900 in Berlin by Meier-Grafe with journalist and editor Otto Julius Bierbaum. Although Graul bought a bronze Laughing Child from Rosso in August 1903, it does not appear in the museum's registers and never entered the museum's collection. ${ }^{82}$

German interest led to a visit by Meier-Graefe and Wilhelm Bernatzik (an impressionist painter who had spent most of his life in Paris) to Rosso's studio in Paris in October 1902. The sculptor was subsequently included in their landmark Vienna Secession exhibition, Entwicklung des Impressionismus in Malerei u. Plastik, from January to February 1903, organised by Meier-Graefe and Bernatzik through a powerful alliance of dealers, collectors and the Secessionists. ${ }^{83}$ Since 1897 , not only had the Secessionists set the standard of modernist culture for Vienna but they also became the main funnel for market distribution. As Jensen establishes, they saw themselves as the heirs of impressionism and the representatives of a 'pan-European impressionist Weltanschauung. ${ }^{84}$ This was, in fact, the first major exhibition of impressionism in Central Europe and it set forth the tenets of modern art, creating a sweeping linear history that culminated in French impressionism.

Rosso's market in Vienna was certainly helped by his presence at the Secession, which demonstrates how internationalism had reshuffled the cards of European art. Meier-Graefe, a German critic, created a Viennese show that inscribed the Italian-born Rosso within a broader history of French impressionism. Rosso was the only Italian modern sculptor included and Giovanni Boldini, listed as 'Jean Boldini,' was the only Italian-born painter. This supports the idea that nineteenth-century Italian art played a most minimal role in the narrative of modernism traced by Meier-Graefe, and that Rosso had gained

81 See: Anon., "Modernes Kunstgewerbe: Impressionistiche Sculptur und Decoration," Leipzig's Illustrierte Zeitung, 25 September 1902.

82 See: L: RG/MR, 6 August 1903 (Archivio Medardo Rosso, Barzio). Rosso recounts this sale to various other people. See: letter from Rosso to Gottfried Eissler, s.d. but from August/ September 1903, written from Leipzig (Archivio Storico delle Arti Contemporanee, Venice, CA 14, fasc. "Medardo Rosso," unpublished, transcription by Alessandro De Stefani). Rosso also recounts the sale in L: MR/GT, s.d. but likely from September 1903; letter from Medardo Rosso to Jehan Rictus, 11 August 1903, Papiers de Jehan Rictus, NaFr24571, 189 R, unpublished, transcription by Alessandro De Stefani.

83 See: letter from Rosso to Wilhelm Bernatzik dated 29 October 1902, published in: Hans Ankwiez von Kleehoven, "Medardo Rosso a Vienna," La biennale di Venezia 23 (1955): 23-4.

84 Jensen, Marketing Modernism, 201. 
access to it through his internationalisation. ${ }^{85}$ His point of origin (as with Boldini) was now noted as Paris. In a critical shift from his earlier grouping with Italians at the exposition universelle, he was now billed among French sculptors Antoine Houdon, Jean-Baptiste Carpeaux, Rodin and Albert Bartholomé, as well as the Belgians Constantin Meunier and Georges Minne. ${ }^{86}$ Rosso's new classification was facilitated by the fact that he had applied for French citizenship in 1902. He believed himself to be part of the international history of modern art, writing to his friend Rictus that, 'in this dozen of names they chose there was naturally mine. ${ }^{87}$ Rosso was also acutely aware of his status as a travelling salesman:

[I am here] to take advantage [...] of whomever has been able to be interested in me and come to know [my works] [...] I come here with two works that I brought with me-my calling cards. Like the ancient Genoese goldsmiths did on their voyages. Visiting with their merchandise. You can see how I live and that many people never see me complain believe I am happy and completely in a good mood and completely at ease. $^{88}$

Rictus's later entry in his diary reflected a less glowing view of Rosso's marketing: 'Poor Rosso, vagabond and street pedlar, who is obliged to make his sales patter all around Europe to offer his works and make a living. ${ }^{89}$ Yet throughout his career, Rosso maintained a sense of humour about his precarious condition.

85 Another "Italian" exception was painter Giovanni Segantini, who had spent most of his career in Switzerland.

86 Rosso was already interested in participating in the Vienna Secession in 19oo. See: letter from Alberto Grubicy to Medardo Rosso dated 11 August 190o, transcribed in: Mola and Vittucci, Medardo Rosso, 46. The letter is preserved in Archivio Medardo Rosso, Barzio.

87 'dans cette dixaine de nom que l'on a choisi il y avait naturellement le mien.' Letter of Medardo Rosso to Jehan Rictus, s.d. but from Vienna, Papiers de Jehan Rictus, NaFr 24571, $387 \mathrm{~V}$, published by Lista, Medardo Rosso. La Sculpture impressionniste, 85. Transcription by Alessandro De Stefani.

88 'Pour profiter ici de qui a pu s'interesser a moi et le connaitre [...] J'en vien avec deux travaus que j'avais porté avec moi-mes cartes de visite. Comme ils fesait les voyages les anciens orfievres genois. Visitant avec leur marchandise. Vois tu comme je vit et que bien des gens me plaignant jamais me croyent heureux et tout a mon bonheur tout a mon aise.' Ibid.

89 'Pauvre Rosso, vagabond et camelot qui est obligé de faire son boniment dans tout l'Europe pour offrir ses œuvres et vivre.' Papiers de Jehan Rictus, NaFr16144, Journal 47, 12 May 1907, 40v. The text was originally transcribed by Alessandro De Stefani. It was later reproduced in Italian translation by Lista in Medardo Rosso. Scultura e fotografia, 315 . 


\section{Rosso's Return to Paris, Vienna and London (1903-7)}

In the first decade of 1900, Rosso rarely exhibited in Paris and we have as yet very few accounts of his sales there. In 1903 he became a founding member of the Salon d'Automne, where he showed works in 1904. While biographies state that he was invited, Barr says that he was refused a separate gallery and thus chose a room adjacent to the Italian sculptor Paul Troubetskoy, in order to elicit a comparison that would prove his superiority. ${ }^{90}$ Despite Rosso's French citizenship, this placement led to a reframing of Rosso as Italian (and Troubetskoy, who was also Italian, as Russian, due to his father's nationality). French critic Louis Vauxcelles expressed the feeling of the French nationalists by calling them 'two foreigners' and contrasting them with what 'the nationalists will say [...] We have Rodin in France.91

Rosso's idiosyncratic installation points to yet another creative strategy he devised to corner a market in Paris. While the catalogue lists his submission to the show generically under the single heading 'Impressions (Bronze et cire),' photographs show he exhibited numerous works (Fig. 8.2).${ }^{92}$ In The Guardian of London, Rosso's acquaintance, the British critic Frances Keyzer, described a series of 'surreptitious [...] snapshots' made by his 'friends.' 93 These 'snapshots' show that Rosso had added his copies of ancient and Renaissance works alongside his sculptures for the first time in an exhibition. Though he had sold them throughout Europe, he had never exhibited them alongside his modern sculptures, a daring manoeuvre for its time. Additionally, the photos reveal that Rosso had furtively placed his sculptures in galleries dedicated to retrospectives of famous French painters Paul Cézanne and Pierre-Auguste Renoir (Fig. 8.3). Tongue in cheek, Keyzer reported that Rosso had also hung photographs of his works - 'accidentally or purposely' - interspersed with photos of works by Rodin. ${ }^{94}$ This might be read as a gesture of protest on Rosso's part for

$90 \quad$ Barr, "Medardo Rosso," 232.

91 'deux étrangers, diront les nationalistes [...] Nous avons Rodin, en France.' Louis Vauxcelles, "Notes d'art: au Salon d'Automne. Le sculpteur Medardo Rosso," Gil Blas, 31 October 1904: 1. It is uncertain how many works Rosso exhibited: Barr noted twenty works in Barr, "Medardo Rosso," 232. Jean-François Rodriguez lists seventeen in JeanFrançois Rodriguez, La réception de l'impressionnisme à Florence en 1910 (Venice: Istituto Veneto di Scienze, Lettere ed Arti, 1994), 5o. Mola and Vittucci list fifteen in Mola and Vittucci, Medardo Rosso, 372.

92 Catalogue de Peinture, Dessin, Sculpture, Gravure, Architecture et Arts Décoratifs, Société du Salon d'Automne (Paris: Évreux, 1904), 161.

93 Frances Keyzer, "Impressionism in Sculpture: A Talk with Medardo Rosso," The Guardian, 2 November 1904.

Ibid. 


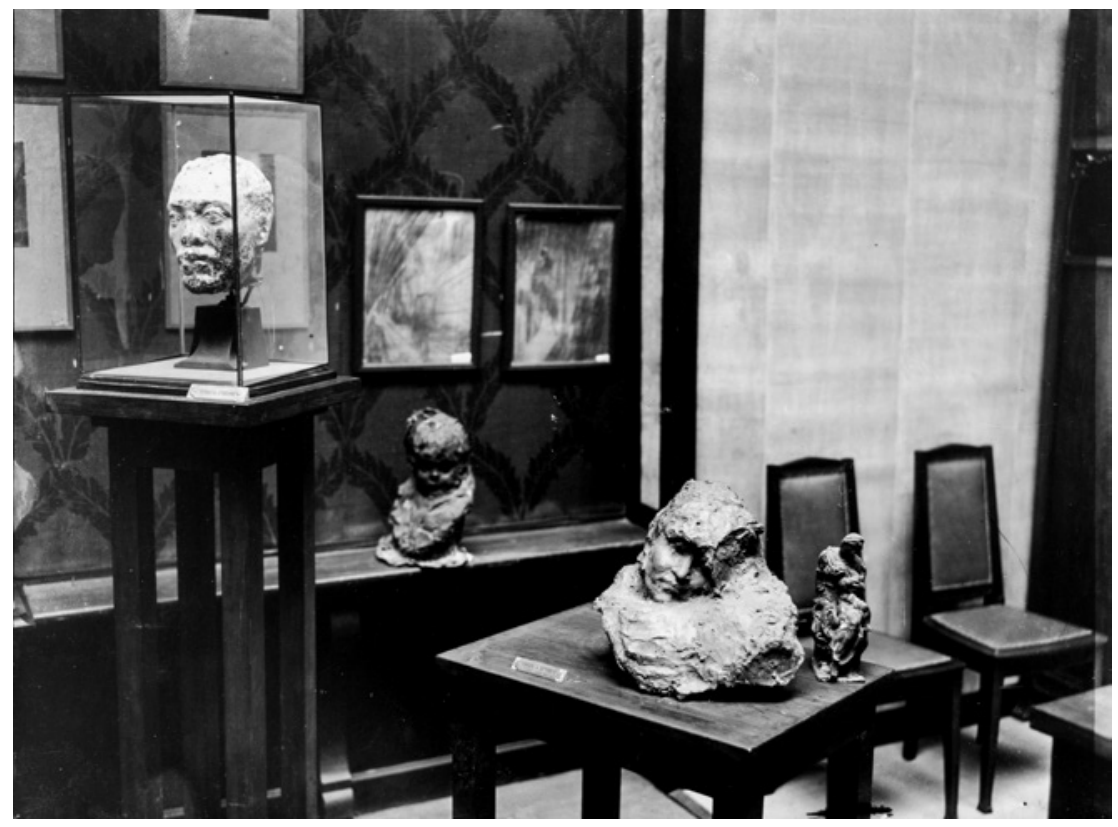

FIGURE 8.2 Unkown photographer, Medardo Rosso, Installation at the Salon d'Automne, 1904

having been rejected by the French. Whatever the circumstances that led to such an act of appropriation, Rosso made a remarkably modern artistic gesture and foreshadowed later conceptual appropriations in avant-garde art.

Rosso told Keyzer in an interview that these unusual placements were by 'the hand of Nemesis.'95 But to German collector Harald Gutherz, Rosso described the show as his great homecoming in France:

I have just had an exhibition at the salon d'authomme champselisse [sic]. They invited me specially and to put my ensemble of works and me up to today to make known my work to everyone, which has been useful to many others bought by celebrities. I accepted. They also asked me to put two of my works in the collection of works by Cezanne and Renoir. That was the most beautiful proof that I am right. That my sculpture goes well with [their painting]. ${ }^{96}$

95 Frances Keyzer, “The Parisians of Paris: A Giant's Struggle," The King, 3 December 1904: 326.

96 'Je viens de faire une exposition au salon d'authomme champselisee. L'on m'a invite specialment et y mettre mon ensemble d'ouvrage e moi jusq'a aujourd'hui faire connaitre par 


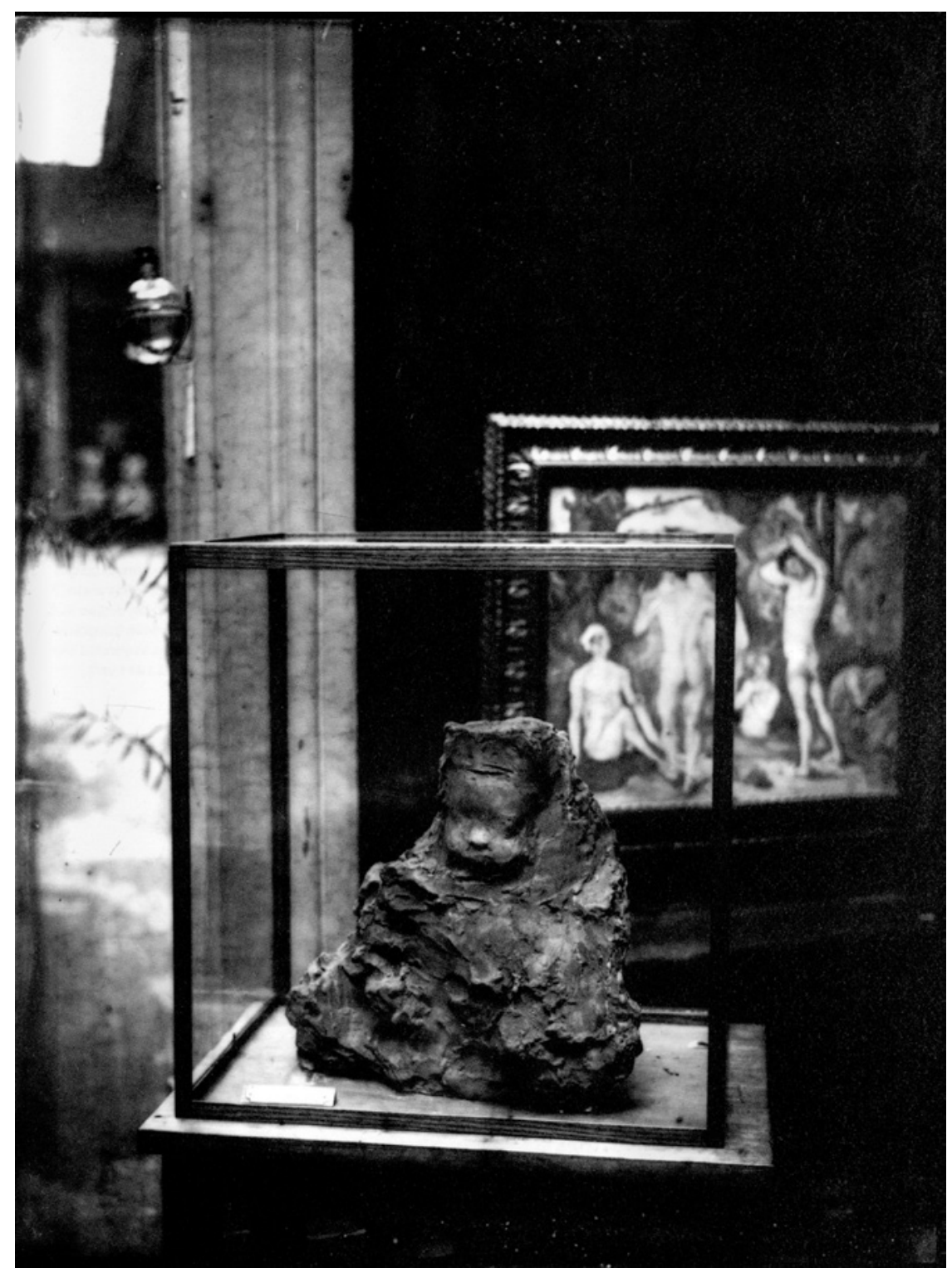

FIGURE 8.3 Unkown photographer, Medardo Rosso, Installation in Salle Cézanne at the Salon d'Automne, 1904 
Not only did Rosso infiltrate French art as a form of remonstration, but he also refused to shake Rodin's hand at the show, ostensibly due to the Balzac affair, but this again provided an opportunity for press coverage. Except for one work submitted to the Salon d'Automne of 1906, this was the last time Rosso exhibited in France.

Rosso returned to Vienna in 1905 for a commercial one-man exhibition, held at Artaria \& Co., an art and antiquities gallery. ${ }^{97}$ Little is known of Artaria, which had exhibited Czech art nouveau painter Alphonse Mucha and Austrian painter Felician von Myrbach. Rosso's casts of ancient copies were now listed for sale along with his works. ${ }^{98}$ He received significant Viennese press coverage, including several reviews by the Austro-Hungarian Ludwig Hevesi, the chief apologist for the Secession. ${ }^{99} \mathrm{He}$ also sold serial works to several Viennese collectors. These include, among others, Hermann and Gottfried Eissler (who bought a bronze Enfant Malade as well as other works), ${ }^{100}$ Erna Brunauer (who bought a wax Bambino ebreo now in a private collection), a certain 'Baronne Eleonora Bach' (who also owned a Bambino ebreo), and a 'Mons. Mendl,' to whom Rosso dedicated another wax Bambino ebreo (now housed in the Österreichische Galerie Belvedere, Vienna).

In this show Rosso for the first time used the Artaria catalogue as an international marketing tool. The catalogue itself was now offered to visitors for sale. Capitalising on serial reproduction, Rosso published names of collections and institutions around Europe that now owned other casts of the same work, in order to give his casts prestigious owners. He also included the 'surreptitious snapshots' of his recent Salon d'Automne infiltration, now billed as a 'large

la toute mon oeuvre, le qui avait été d'utilité a bien d'autres celebrités achetée. Ai accepté. Meme l'on m'a prie mettre deux de mes ouvrages, dans la collection aussi des ouvrages a Cezanne et a Renoir. Cela a fait la plus belle preuve que ai raison. Ce que ma sculpture vais bien avec.' Letter from Medardo Rosso to Harald Gutherz, s.d. but end of 1904, published in: Giorgio Nicodemi, "Le gamin souriant' e cinque lettere di Medardo Rosso," Emporium, 83, no. 498 (1936): 300 .

97 The agreement was signed on 27 May 1903 for January of 1904, but the show was postponed to 1905. See letter of agreement: Wienbibliothek Artaria Archiv, Vienna, autographenbox, 22, cited but not transcribed in Mola, Medardo Rosso, 309.

98 See Rosso's copy of Medardo Rosso: Bronzen, Impressionen in Wachs, Kunstsalon Artaria, February 1905 (Archivio Medardo Rosso, Barzio). Prices are listed by hand in the margins.

99 Ludwig Hevesi, "Medardo Rosso," Kunst und Kunsthandwerk 8 (1905): 174-82.

100 See: Sharon Hecker, "An Enfant malade by Medardo Rosso from the Collection of Louis Vauxcelles," The Burlington Magazine 152 (2010): 727-35. 
collective exhibition.' ${ }^{101}$ Finally, he added glowing reviews by prestigious critics from around Europe and the United States, including a bit from Meier-Graefe's new volume. The catalogue also advertised Claris's enquête (which "proved" that Rosso "belonged" to French impressionism and was internationalised in its German translation) for sale at the show. Rosso would later amplify this grand marketing strategy for another lavish catalogue at his personal exhibition at the Cremetti Gallery in London in December 1906, creating what Barr called 'a gigantic publicity release.' 102

In 1905, as the Fauves debuted at the Salon d'Automne and French critics hailed impressionism as dead, a major impressionist show was mounted in London, in which Rosso did not participate. Yet I believe that his subsequent period in London can be contextualised as part of the continued internationalisation of impressionism and Rodin's undying success abroad. In late 1905 Rosso was commissioned by the British Jewish industrialist Emile Mond and his wife, Angela, to make a portrait of their young son, Alfred William (who would commit suicide at age twenty-seven). The family immediately rejected the work, claiming it did not resemble their son, but today it is considered Rosso's masterpiece (Ecce puer). ${ }^{103}$ Until 1907 Rosso's name continued to appear in the British press, especially following a well-publicised battle with the International Society of Sculptors, Painters, and Gravers of which Rodin was president.

\section{From France and Back to Italy (1906-10)}

Rosso still made efforts to gain institutional acceptance, no doubt realising that in spite of all his creative marketing strategies, the best way to promote his works was still through an entrance into a national museum. Biographies cite the acquisition of Aetas aurea (Golden Age, late 1885-86) for the Petit Palais at the end of 1907, and Georges Clemenceau's acceptance of Ecce puer and Femme à la Voilette (Lady with a Veil, c. 1892-97) for the Luxembourg Museum, as a sign of the French recognition of Rosso's work. The reality turns out to be more complicated. After an offer to buy Femme à la Voilette from the French State for a low sum, Rosso, trying to negotiate for the acceptance of Ecce puer, which he

\footnotetext{
101 'große Kollektiv-Austellung.' Medardo Rosso: Bronzen, Impressionen in Wachs, Kunstsalon Artaria, February 1905 (Archivio Medardo Rosso, Barzio).

102 Barr believes it was paid for by Fles in Barr, "Medardo Rosso," 234.

103 For a detailed history of the work, see: Sharon Hecker, "Ecce Puer," in Da Hayez a Klimt. Maestri dell'Ottocento e Novecento della Galleria Ricci Oddi, ed. Stefano Fugazza (Milan: Skira, 1997), 147-9.
} 
considered his masterpiece, ended up donating it. Femme à la Voilette was never inventoried and was shipped to the provincial museum of Lyon in 1931. Despite Rosso's French citizenship, Ecce puer, exhibited at the Luxembourg Museum from 1908, was put into storage in 1920, to be installed in a future museum dedicated to the 'School of Foreigners,' which would never be constructed.

Hoping to find new markets in Italy, Rosso returned after a long hiatus to participate in his first exhibition there in 1910, La prima mostra dell'impressionismo francese e delle scolture di Medardo Rosso, organised by Ardengo Soffici in Florence. The show was intended to introduce Italians to French impressionism. What was promoted as Rosso's triumphant homecoming after a twentyone year absence - now as an affirmed cosmopolitan artist and recognised by the world as part of French impressionism-instead elicited ferocious nationalistic criticism that Rosso had suppressed his Italian roots.

At the same time, Rosso's patroness Etha Fles attempted to generate an Italian institutional acceptance for Rosso in different ways than Soffici's campaign. She could no longer support Rosso financially by then. ${ }^{104}$ In order to advance his career in Italy, she proposed to sell Rosso's works from her collection to Italian museums. She wrote to directors that, 'it would be psychologically such a good thing for Medardo Rosso if Italy actually bestirred herself for him. If Italy were not his own country he would not mind quite so much this animosity, this hostility towards him.'105 To entice them, she cited his international acceptance, listing his works at the Luxembourg, and in collections in Dresden, Hagen and Leipzig. This was apparently no easy task, which she described as 'forcing' museums to buy one work each while donating several others. ${ }^{106}$ With very few exceptions, Rosso's return to Italy sounded the death knell for his international sales. Because of events leading up to World War I, which caused a fierce nationalistic regression, Rosso was not able to maintain his international marketing approach over the next several decades.

\section{References}

Ankwiez von Kleehoven, Hans. "Medardo Rosso a Vienna." La biennale di Venezia 23 (1955): 23-4.

Anon. "L'Amore materno." L'Illustrazione italiana (1886): 406 and 418.

Anon. "À L’Exposition." L'éclair, 22 May 19oo: 2.

104 Barr, "Medardo Rosso," 240.

105 Letter from Etha Fles to Nino Barbantini, quoted in Barr, "Medardo Rosso," 247.

106 Ibid. 
Anon. "Modernes Kunstgewerbe: Impressionistiche Sculptur und Decoration." Leipzig's Illustrierte Zeitung, 25 September 1902.

Anon. "Goupil \& Cie/Boussod, Valadon \& Cie Stock Books." The Getty Research Institute. http://www.getty.edu/research/tools/digital_collections/goupil_cie/.

Barbesi, Gaetano. L'indicatore della colonia italiana di Parigi. Paris: Tipografia del Risveglio italiano, 1905.

Beattle, Susan. Alfred Stevens, 1817-75. London: Victoria \& Albert Museum, 1975.

Bestaggini, Antonella E.A. "The Italian Exhibition of 1888 at Earl's Court." MA thesis, Courtauld Institute, 1990.

Boime, Albert. The Art of the Macchia and the Risorgimento: Representing Culture and Nationalism in Nineteenth-Century Italy. Chicago: University of Chicago Press, 1993.

Bomben, Giuseppe. "Esposizione delle opere di belle arti in Brera, VII." Il Secolo, 23 September 1869 .

Callen, Anthea. "Faure and Manet." Gazette des beaux-arts (1974): 157-78.

Caramel, Luciano. Mostra di Medardo Rosso (1858-1928). Milan: Società per le belle arti ed esposizione permanente, 1979.

Caso, Jacques de. “Serial Sculpture in Nineteenth-Century France." In Metamorphoses in Nineteenth-Century Sculpture, edited by Jean Wasserman, 1-27. Cambridge: Harvard University Press, 1979.

Caso, Jacques de. "Gustave Moreau, l'envers de la sculpture." In Gustave Moreau: l'homme aux figures de cire, 7-13. Paris: Somogy, 2010.

Catalogue de Peinture, Dessin, Sculpture, Gravure, Architecture et Arts Décoratifs. Société du Salon d'automne. Paris: Évreux, 1904.

Catalogue des Objets de curiosité. Hôtel Drouot, 17 February 1886.

Chabod, Federico. Storia della politica estera italiana dal 1870 al 1896. 2 vols. Bari: Laterza, 1951.

Chevillot, Catherine, ed. Emmanuel Frémiet: La main et le multiple. Dijon: Musée des Beaux-Arts, 1988.

Claris, Edmond. De l'Impressionnisme en sculpture: lettres et opinions de Rodin [et al.]. Paris: Éditions de La Nouvelle Revue, 1902.

Claris, Edmond. Souvenirs de soixante ans de journalisme 1895-1955. Paris: José MillasMartin, $195^{8}$.

Corgnati, Maurizio, Gianlorenzo Mellini, and Francesco Poli, eds. Il lauro e il bronzo. La scultura celebrative in Italia. 1800-1900. Moncalieri: Ilte, 1990.

Dalligny, August. “Le Salon de 1886.” Journal des arts, 30 April 1886.

De Brinn'Gaubast, Louis-Pilate. “L'Exposition des artistes indépendants." Le Décadent, 18 September 1886.

De Sainte-Croix, Camille. “Medardo Rosso." Mercure de France 17 (March 1896): 378-91.

Dumas, François-Guillaume, ed. Catalogue illustré du Salon. Paris: Librairie d'art Ludovic Baschet, 1885 . 
Esner, Rachel. “'Art Knows no Fatherland': Internationalism and the Reception of German Art in France in the Early Third Republic." In The Mechanics of Internationalism, edited by Martin H. Geyer and Johannes Paulmann, 357-74. London: Oxford University Press, 2001.

Fletcher, Pamela, and Anne Helmreich. "Local/Global: Mapping Nineteenth-Century London's Art Market." Nineteenth-Century Art Worldwide 11, no. 3 (2012), http:// www.19thc-artworldwide.org/index.php/autumn12/fletcher-helmreich-mappingthe-london-art-market.

Fontana, Federico. "I nuovi monumenti al Cimitero Monumentale di Milano." L'Italia, 2-3 November 1889 .

Galenson, David W., and Robert Jensen. "Careers and Canvases: The Rise of the Market for Modern Art in Nineteenth-Century Paris." Van Gogh Studies (Current Issues in Nineteenth-Century Art) 1 (2007): 137-66.

Gardonio, Matteo. "Scultori italiani alle Esposizioni Universali di Parigi (1855-1889): aspettative, successi e delusioni." PhD diss., Università degli Studi di Trieste, 2008.

Gariff, Davide Martin. "Giuseppe Grandi (1843-1894) and the Milanese Scapigliatura." PhD diss., University of Maryland, 1991.

Gazzetta Ufficiale del Regno d'Italia, 7 September 1910.

Giorio, Maria Beatrice. "Gli scultori italiani e la Francia. Influenze e modelli francesi nella prima metà del novecento." PhD diss., Università degli Studi di Trieste, 2010-11.

Hargrove, June. "Qui Vive? France: Sculpture of the Revanche." In Nationalism and French Visual Culture, 1870-1914, edited by June Hargrove and Neil McWilliam, 5582. New Haven - London: Yale University Press, 2005.

Hargrove, June. "Introduction." In Nationalism and French Visual Culture, 1870-1914, edited by June Hargrove and Neil McWilliam, 9-16. New Haven - London: Yale University Press, 2005.

Hecker, Sharon. "Ecce Puer." In Da Hayez a Klimt. Maestri dell'Ottocento e Novecento della Galleria Ricci Oddi, edited by Stefano Fugazza, 147-9. Milan: Skira, 1997.

Hecker, Sharon. "Reflections on Repetition in the Sculpture of Medardo Rosso." In Medardo Rosso: Second Impressions, 23-67. New Haven - London: Yale University Press, 2003.

Hecker, Sharon. "Fleeting Revelations: The Demise of Duration in Medardo Rosso's Wax Sculpture." In Ephemeral Bodies: Wax Sculpture and the Human Figure, edited by Roberta Panzanelli, 131-53. Los Angeles: J.P. Getty Trust, 2008.

Hecker, Sharon. "Il centro non può reggere: la monumentalità impossibile di Medardo Rosso." In Patrioti si diventa. Luoghi e linguaggi di pedagogia patriottica nell'Italia unita, edited by Arianna Arisi Rota and Matteo Morandi, 185-198. Milan: Franco Angeli, 2009.

Hecker, Sharon. "An Enfant malade by Medardo Rosso from the Collection of Louis Vauxcelles." The Burlington Magazine $15^{2}$ (2010): 727-35. 
Hecker, Sharon. "Everywhere and Nowhere: Medardo Rosso and the Cultural Cosmopolitan in Fin-de-siècle Paris." In Strangers in Paradise: Foreign Artists and Communities in Modern Paris, 1870-1914, edited by Susan Waller and Karen Carter, 143-54. Aldershot: Ashgate, 2015.

Hecker, Sharon. A Moment's Monument: Medardo Rosso and the International Origins of Modern Sculpture. Berkeley: University of California Press, 2017.

Hevesi, Ludwig. "Medardo Rosso." Kunst und Kunsthandwerk 8 (1905): 174-82.

Hoffmann, F. "Le Salon des Indépendants." La Bataille, 4June 1885: 2.

Illustrated Catalogue of Alberto Grubicy's Picture Gallery in the Italian Exhibition in London, with a Preface and Biographical Notes by Vittore. Milan: Grubicy, 1888.

James, Duncan S. A Century of Statues: A History of the Morris Singer Foundry. Basingstoke: The Morris Singer Foundry, 1984.

Jensen, Robert. Marketing Modernism in Fin-de-Siècle Europe. Princeton: Princeton University Press, 1994.

Johnston, William, and Simon Kelly. Untamed: The Art of Antoine-Louis Barye. Munich - New York: Prestel, 2006.

Keyzer, Frances. "Impressionism in Sculpture: A Talk with Medardo Rosso." The Guardian, 2 November 1904.

Keyzer, Frances. “The Parisians of Paris: A Giant's Struggle.” The King, 3 December 1904: 326.

Krahn, Volker. "Pastiche or Fake? A 'Donatello' by Medardo Rosso.” Apollo (June 2009): 40-7.

Lagrange, Marion. Les Peintres italiens en quête d'identité. Paris 1855-1909. Paris: INHA/ CTS, 2009.

Lamberti, Maria Mimita. "Il mercato della pittura italiana negli anni settanta." In Storia dell'arte italiana, 5-62. Turin: Einaudi, 1982.

Langely. “La Sculpture Au Salon de 1886." Journal des artistes, 9 May 1886.

La sculpture française au XIX ${ }^{e}$ siècle. Paris: Réunion des musées nationaux, 1986.

Lebon, Elisabeth. Dictionnaire des fondeurs de bronze d'art, France 1890-1950. Paris: Marjon Éditions, 2003.

Lebon, Elisabeth. Faire-Fonte au sable-Fonte à cire perdue. Paris: Ophrys Édition, 2012.

Lista, Giovanni. Medardo Rosso. Destin d'un Sculpteur. Paris: L'Échoppe, 1994.

Lista, Giovanni. Medardo Rosso: La Sculpture impressionniste. Paris: L’Échoppe, 1994.

Lista, Giovanni. Medardo Rosso. Scultura e fotografia. Milan: 5 Continents editions, 2003.

Mainardi, Patricia. The End of the Salon: Art and the State in the Early Third Republic. Cambridge - New York: Cambridge University Press, 1993.

Mapping the Practice and Profession of Sculpture in Britain and Ireland 1851-1951, University of Glasgow History of Art and HATII, online database 2011. http://sculp ture.gla.ac.uk/view/person.php?id=ann_1356906205 (accessed 5 October 2014). 
Massobrio, Giovanni. L'Italia per Garibaldi. Milan: SugarCo, 1982.

McWilliam, Neil. "Craft, Commerce and the Contradictions of Anti-Capitalism: Reproducing the Applied Art of Jean Baffier." In Sculpture and its Reproductions, edited by Anthony Hughes and Erich Ranfft, 100-12. London: Reaktion Books, 1997.

Meier-Graefe, Julius. Entwicklungsgeschichte der modernen Kunst. Stuttgart: Julius Hoffmann, 1904.

Middleton Wagner, Anne. Jean-Baptiste Carpeaux: Sculptor of the Second Empire. New Haven: Yale University Press, 1986.

Mola, Paola Rita. "Medardo Rosso, due lettere a Felice Cameroni." E.S. 6 (1977): 121-6.

Mola, Paola, and Fabio Vittucci. Medardo Rosso. Catalogo ragionato della scultura. Milan: Skira, 2009.

Morice, C. "Les Passants: Medardo Rosso." Le Soir, 25 September 1895.

Nicodemi, Giorgio. “Le gamin souriant' e cinque lettere di Medardo Rosso." Emporium 83, no. 498 (1936): 296-302.

Oldani, Alessandro. "Medardo Rosso, 1858-1928." In Medardo Rosso. La luce e la materia, edited by Paolo Zatti, 113-22. Milan: 24 Ore Cultura, 2015.

Parlanti, Steve. The Parlantis: Art Bronze Founders of Fulham. London: Troubador Publishing, 2010.

Pécout, Gilles. Il lungo Risorgimento. La nascita dell'Italia contemporanea (1770-1922). Milan: Bruno Mondadori, 2000.

Piantoni, Gianna, and Anne Pingeot, eds. Italie 1880-1910. Arte alla prova della modernità. Turin: Umberto Allemandi, 2000.

Piantoni, Gianna, and Anne Pingeot, eds. Italies 1880-1910. L'art italien à l'épreuve de la modernité. Paris: Réunion des musées nationaux, 2001.

Piérard, Louis. Un sculpteur impressionniste: Medardo Rosso. Paris - Mons: Éditions de la Société nouvelle, 1909.

Porciani, Ilaria. "Stato e nazione: l'immagine debole dell'Italia." In Fare gli italiani. Scuola e cultura nell'Italia contemporanea, edited by Simonetta Soldani and Gabriele Turi, vol. 1, 385-428. Bologna: Il Mulino, 1993.

Py, Robert. "Le Salon du Groupe des Artistes Indépendants." Revue moderne, 1 June 1885: 354 .

Rambaud, Yveling. Silhouettes d'Artistes. Paris: Société Française d'Éditions d'Art, 1899 .

R.D. “Aus dem Berliner Kunstleben." National Zeitung, 24 January 1902.

Report. Part Four-Regulations, Forms, Catalogue. Chapter III. Catalogue of the Fine Art Section. Class XV. SCULPTURE. London: Waterlow and Sons, 1889.

Riall, Lucy. Garibaldi: Invention of a Hero. New Haven: Yale University Press, 2007.

Riall, Lucy. "Eroi maschili, viriltà e forme della guerra." In Storia d'Italia. Annali 22. Il Risorgimento, edited by Alberto Mario Banti and Paul Ginsborg, 253-88. Turin: Einaudi, 2007. 
Rictus, Jehan. “Un Précurseur: Medardo Rosso." Comœdia, 3 January 1913.

Rionnet, Florence. La maison Barbedienne: correspondances d'artistes. Paris: стнs, 2008.

Rodin en 19oo. L'exposition de l'Alma. Paris: Réunion des musées nationaux, 2001.

Rodriguez, Jean-François. La réception de l'impressionnisme à Florence en 1910. Venice: Istituto Veneto di Scienze, Lettere ed Arti, 1994.

Rouart, Eugène. "En souvenir de Medardo Rosso." L'Archer, nouvelle série 4 (1930): 281-5.

Scolari Barr, Margaret. "Medardo Rosso and his Dutch Patroness." Nederlands Kunsthistorisch Jaarboek 13 (1962): 217-51.

Tentoonstelling van schilderijen uit de moderne Fransche school en beeldhouwwerken van M. Rosso. Januari-Februari 19o1. S.l.: Arti et Amicitiae, 1901.

Thiaudière, Edmond. "Au Salon: La Sculpture-Les Bustes, II, Medardo Rosso." L'Opinion, 2 June 1886.

Thormann, Olaf. Die Museumschronik von den Anfängen bis zum Jahr 1929. Leipzig: Passage-Verlag, 2003.

Vauxcelles, Louis. "Notes d'art: au Salon d'Automne. Le sculpteur Medardo Rosso." Gil Blas, 31 October 1904: 1.

White, Harrison C., and Cynthia A. White. Canvases and Careers: Institutional Change in the French Painting World. New York: Wiley, 1965. 